OPEN ACCESS

Edited by:

Ibrahim F. Shatat,

Sidra Medical and Research Center,

Qatar

Reviewed by:

Brian Christopher Bridges, Vanderbilt University, United States

Michael L. Moritz,

University of Pittsburgh School of

Medicine, United States

*Correspondence:

Rupesh Raina

rraina@akronchildrens.org;

raina@akronnephrology.com

†These authors share first authorship

Specialty section:

This article was submitted to

Pediatric Nephrology,

a section of the journal

Frontiers in Pediatrics

Received: 14 June 2018

Accepted: 28 September 2018

Published: 29 October 2018

Citation:

Raina R, Sethi SK, Wadhwani N, Vemuganti $M$, Krishnappa $V$ and Bansal SB (2018) Fluid Overload in

Critically III Children

Front. Pediatr. 6:306

doi: 10.3389/fped.2018.00306

\section{Fluid Overload in Critically III Children}

\author{
Rupesh Raina ${ }^{1,2 * t}$, Sidharth Kumar Sethi ${ }^{3 \dagger}$, Nikita Wadhwani ${ }^{3}$, Meghana Vemuganti ${ }^{4}$, \\ Vinod Krishnappa ${ }^{2,5}$ and Shyam B. Bansal ${ }^{3}$ \\ ${ }^{1}$ Department of Nephrology, Akron Children's Hospital and Cleveland Clinic Akron General, Akron, $\mathrm{OH}$, United States, ${ }^{2}$ Akron \\ Nephrology Associates, Cleveland Clinic Akron General, Akron, OH, United States, ${ }^{3}$ Department of Nephrology, Kidney \& \\ Urology Institute, Medanta, The Medicity, Gurgaon, India, ${ }^{4}$ College of Medicine, Northeast Ohio Medical University, \\ Rootstown, OH, United States, ${ }^{5}$ College of Graduate Studies, Northeast Ohio Medical University, Rootstown, OH, \\ United States
}

Background: A common practice in the management of critically ill patients is fluid resuscitation. An excessive administration of fluids can lead to an imbalance in fluid homeostasis and cause fluid overload (FO). In pediatric critical care patients, FO can lead to a multitude of adverse effects and increased risk of morbidity.

Objectives: To review the literature highlighting impact of $\mathrm{FO}$ on a multitude of outcomes in critically-ill children, causative vs. associative relationship of FO with critical illness and current pediatric fluid management guidelines.

Data Sources: A literature search was conducted using PubMed/Medline and Embase databases from the earliest available date until June 2017.

Data Extraction: Two authors independently reviewed the titles and abstracts of all articles which were assessed for inclusion. The manuscripts of studies deemed relevant to the objectives of this review were then retrieved and associated reference lists hand-searched.

Data Synthesis: Articles were segregated into various categories namely pathophysiology and sequelae of fluid overload, assessment techniques, epidemiology and fluid management. Each author reviewed the selected articles in categories assigned to them. All authors participated in the final review process.

Conclusions: Recent evidence has purported a relationship between mortality and FO, which can be validated by prospective RCTs (randomized controlled trials). The current literature demonstrates that "clinically significant" degree of FO could be below $10 \%$. The lack of a standardized method to assess FB (fluid balance) and a universal definition of FO are issues that need to be addressed. To date, the impact of early goal directed therapy and utility of hemodynamic parameters in predicting fluid responsiveness remains underexplored in pediatric resuscitation.

Keywords: fluid overload, acute kidney injury, critical care, pediatric nephrology, intensive care

\section{INTRODUCTION}

In a critically ill patient, fluid balance is imperative in management and maintaining homeostasis. More often than not, patients are resuscitated with fluids to maintain adequate intravascular volume. A common issue seen in pediatric intensive care units is fluid imbalances and hemodynamic instability. Aggressive fluid administration can lead to fluid overload (FO), a 
condition in which there is a positive fluid balance in the patient. This phenomenon has been associated with a multitude of unfavorable effects and can further complicate the patient's condition. While FO itself is no indicator of mortality, the adverse effects of FO on an already at risk population puts them at an increased risk of morbidity and mortality. Research on this commonly practiced standard of care has shown that inundation is not always the best method for hemodynamic optimization. Current literature shows that there is a lack of a standard definition of fluid overload and a standard guideline by which to direct fluid therapy. The purpose of this study was to review the literature highlighting the impact of FO on a multitude of outcomes in critically-ill children, analyzing the causative vs. associative relationship of FO with critical illness, and addressing the current pediatric fluid management guidelines.

\section{METHODS}

The literature search was conducted using PubMed/Medline, and Embase databases for studies on fluid overload in pediatric critical care patients $<18$ years, from the earliest available date until June 2017. A total of 477 articles were obtained; after duplicate removal and review, 48 articles were selected for data extraction (Figure 1). The initial literature review consisted of two authors who independently reviewed the articles. The manuscripts of studies deemed relevant to the objectives of this review were then retrieved and associated reference lists handsearched. Articles were categorized into FO associated with renal replacement therapy, extracorporeal membrane oxygenation, cardiac surgery, neonates, respiratory tract disease, and sepsis. All relevant publications were considered for data extraction. Tables were created summarizing the outcomes of the included studies.

\section{PATHOPHYSIOLOGY OF FLUID OVERLOAD}

Current understanding of FO is contingent upon the revised Starling law which ascribes an important role to EGL (endothelial glycocalyx) in maintaining an intact vascular biology. EGL, a web of membrane-bound glycoproteins and proteoglycans on the luminal surface of endothelium, binds to plasma proteins and effectively excludes proteins from the sub-endothelial cleft, thereby resulting in a local oncotic gradient between plasma and cleft which opposes trans-capillary efflux (1). The law states that a constant oncotic gradient present along capillaries opposes pressure-mediated fluid efflux without ever causing fluid reabsorption from interstitium (except for vascular beds in renal tubules and intestines), and almost all vascular refilling from interstitium occurs via lymphatics (2). EGL breakdown can be triggered by various processes and stresses such as sepsis, surgery, postischemic states, and hyperglycemia (2-7). Once the EGL is damaged, fluid efflux becomes primarily dependent on capillary hydrostatic pressure and the manipulation of plasma oncotic pressure with colloids does not encourage any vascular refilling. In addition to fluid and protein extravasation, EGL disruption potentiates ongoing inflammatory responses by exposing endothelial cell-adhesion molecules and may account for pathologies with interstitial edema such as acute lung injury (4). In experimental and perioperative settings, volume expansion has been shown to hasten glycocalyx disintegration and reduce lymphatic drainage through release of natriuretic peptides. In addition to cleaving membrane-bound proteoglycans and glycoproteins (most notably syndecan-1 and hyaluronic acid) off endothelial glycocalyx, they also reduce lymphatic drainage by inhibiting lymphatic propulsive motor activity $(3,4)$. This worsens FO because interstitial fluid is primarily channeled back into circulation via lymphatics.

Of note, some data regarding glycocalyx and natriuretic peptides is partly theoretical, and partly derived from adult studies and there is no pediatric-specific data in this context $(8-10)$.

\section{QUANTIFYING FLUID OVERLOAD}

Despite the burgeoning evidence regarding association between FO and adverse patient outcomes, there is no consensus on the optimal method for calculating FO. Lombel et al. highlighted that depending upon the definition used, there was a significant variability in the number of patients identified with $>10 \%$ FO (11).

Most pediatric studies utilize the FB method introduced by Goldstein et al. (12). The formula is:

$$
\% F O=\frac{(\text { daily fluid intake }(L)-\text { total output }(L))}{\text { Baseline body weight }(\mathrm{kg})} \times 100
$$

More practical WB(weight based) methods can be alternatively used to estimate degree of FO. The formulas are:

$$
\% \mathrm{FO}=\frac{\left(\begin{array}{c}
\text { CRRT initiation weight }(\mathrm{kg})- \\
\text { hosptial admission weight }(\mathrm{kg})
\end{array}\right)}{\text { hosptial admission weight }(\mathrm{kg})} \times 100
$$

or

$$
\% F O=\frac{\left(\begin{array}{c}
C R R T \text { initiation weight }(\mathrm{kg})- \\
\text { ICU admission weight }(\mathrm{kg})
\end{array}\right)}{\text { ICU admission weight }(\mathrm{kg})} \times 100 .
$$

These are particularly useful in neonates because of uncertainties in estimating fluid input via breastmilk, fluid lost into diapers/bedsheets, and insensible losses apart from losses which can be markedly influenced by a number of factors (13). ICU admission weights when taken as baseline might under-estimate degree of FO in comparison to hospital admission weight. This discrepancy may also delay CRRT (continuous renal replacement therapy) initiation as most clinicians still consider $10 \%$ as the threshold to intervene (14). Multiple studies in both adult and pediatric literature have demonstrated poor agreement between changes in body weight and FO (Table 2). Nonetheless, reports have shown correlation between the two and a similar predictive potential of mortality (15). These inconsistent results warrant further research to recognize the most appropriate method of FO measurement. 

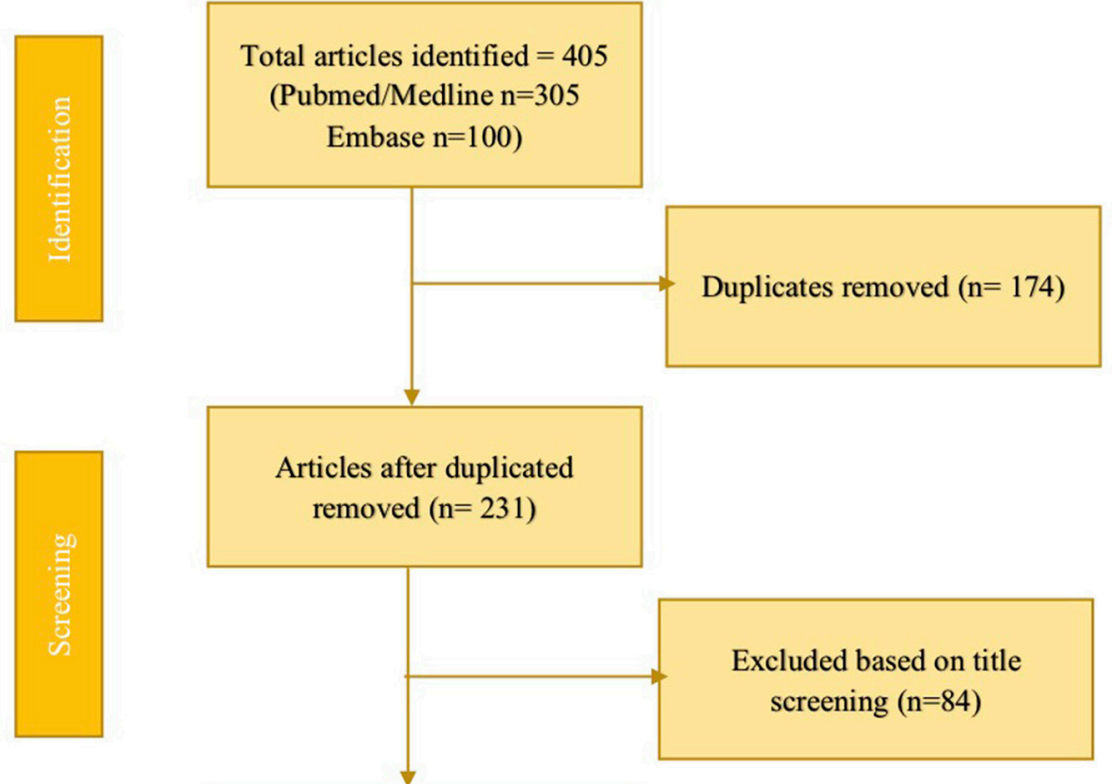

Articles considered for abstract screening $(n=147)$
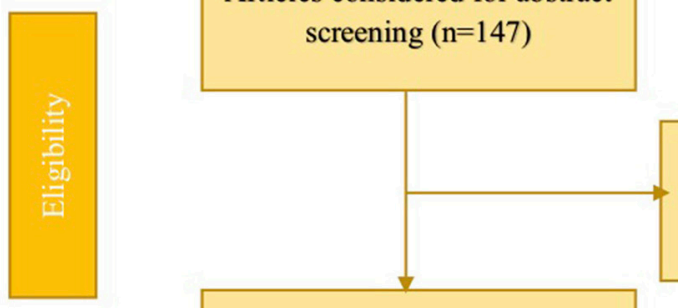

Excluded based on abstract screening $(n=53)$

Articles considered for full text review $(n=87)$
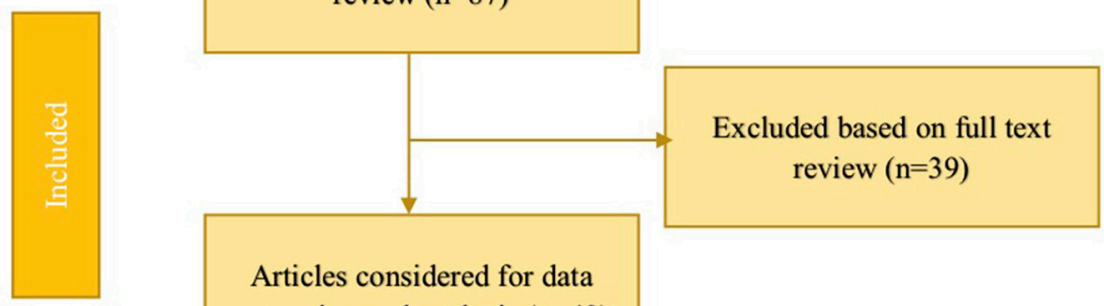

Articles considered for data extraction and analysis $(n=48)$

FIGURE 1 | Summary of literature search.

\section{IS FLUID OVERLOAD EVER INDEPENDENT OF AKI?}

FO has detrimental effects on all organs, notably kidneys (2) (Figure 2). It is not just an epiphenomenon in AKI because FO per se renders an individual vulnerable to AKI and often predates it $(23,24)$. The development of abdominal hypertension and abdominal compartment syndrome impairs renal perfusion, and can culminate in a vicious cycle of AKI and FO (25). Deferral of AKI diagnosis correlates with the degree of fluid overload (Table 1). The risk of FO in this setting is that it can increase the volume of distribution of serum creatinine, a measure of
AKI, leading to an overestimation of kidney function and a delayed diagnosis of AKI $(26,27)$. In scenarios where FO was not accounted for, patients with a decreasing trend in $\mathrm{sCr}$ (serum creatinine) had increased mortality than patients with high $\mathrm{sCr}$ and severe AKI (28).

The following equation can be used to adjust $\mathrm{sCr}$ for fluid accumulation: adjusted $\mathrm{Cr}=\mathrm{sCr}[1+(\mathrm{Net}$ fluid balance/Total body water)], where TBW $=0.6 \times$ weight $(\mathrm{kg})(29)$. However, use of the constant 0.6 in estimating TBW may not be accurate in all patients as it can be affected by age, sex, and various pathologic states (heart failure, cirrhosis, nephrosis).

Re-analysis of FACTT (Fluid and Catheter Treatment Trial) showed that presence of covert AKI was independently associated 
with a higher risk of death. Incidence of AKI was greater in the conservative arm before adjustment but in liberal arm post-adjustment (30). Secondary analysis of PICARD (Program to Improve Care in Renal Disease) cohort also revealed that correction for $\% \mathrm{FO}$ uncovered missed diagnoses and reclassified AKI in some patients. Although no mortality differences were noted, the need for subsequent dialysis was higher in the misdiagnosed patients (27). Basu et al. reiterated these findings in 92 infants undergoing arterial switch operation wherein correction of $\mathrm{sCr}$ for FO not only increased AKI prevalence but also strengthened its association with postoperative morbidities (29).

\section{EPIDEMIOLOGY AND OUTCOMES}

\section{Fluid Overload and Adverse Outcomes: Does Current Evidence Endorse Causality?} With the exception of select adult trials and recent findings of Grams et al. (31-36), no pediatric study to date has demonstrated FO as a causal contributor to mortality rather than just a marker

TABLE 1 | Common methods to calculate the degree of fluid overload.

\begin{tabular}{|c|c|}
\hline Fluid balance based methods & Weight based methods \\
\hline $\begin{array}{l}\text { 1. } \frac{\text { Fluid in-fluid out }}{\text { PlCU adm wt }} \times 100 \\
\text { 2. } \frac{\text { Fluid in-fluid out }}{\text { hosp adm wt }} \times 100 \\
\text { 3. } \frac{\text { Fluid in- fluid out }}{\text { PlCU dry wt }} \times 100\end{array}$ & 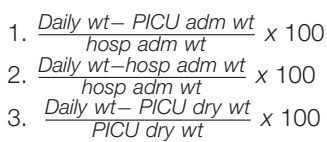 \\
\hline
\end{tabular}

adm, admission; wt, weight; hosp, hospital. of disease severity. In their post-hoc analysis of FACTT, Grams et al. showed FO as a causal intermediate in the association between diuretic administration and decreased mortality in AKI patients, suggesting that the mortality benefit associated with furosemide was due to a decrease in FO (35). Few pediatric studies have in fact shown that FO is a significant co-morbidity that is highly associated with adverse outcomes only in patients with limited disease unlike patients with severe disease in whom the ultimate outcome is independent of $\% \mathrm{FO}$, suggesting that the disease severity itself is the primary determinant (37-39).

\section{Renal Replacement Therapy}

There are many indications for initiating renal replacement therapy (RRT) in a critically ill patient, FO being one of them. RRT provides control in fluid management and allows for the ability to achieve a negative fluid balance (40). Association between FO and mortality was first observed by pediatricians in critically ill children with AKI requiring RRT. Several pediatric studies have demonstrated an independent association between FO at the time of continuous renal replacement therapy (CRRT) initiation with mortality (41-45). A study by Goldstein looked at 116 pediatric intensive care unit patients with multiorgan dysfunction who received CRRT. The results showed a significant survival different in patients who were in a state of FO while on CRRT vs. those who are able to achieve their dry weight (36 vs. 76\%) (43). The results from the ppCRRT Registry stratifying 297 patients into $<10 \%, 10-20 \%$, and $>20 \%$ FO groups remain most comprehensive in this regard (41). Analysis revealed that presence of FO at CRRT initiation was associated with raised

TABLE 2 | Studies assessing the correlation and agreement between the fluid balance and weight based methods of fluid overload estimation.

\begin{tabular}{|c|c|}
\hline Study author & Conclusion \\
\hline van Asperen et al. (13) & $\begin{array}{l}\text { Fluid balance charts both over and under-estimate body weight change and are unreliable as a single measure of fluid status in } \\
\text { neonates }\end{array}$ \\
\hline Selewski et al. (15) & Both the methods were similar in predicting the degree of FO at CRRT initiation and mortality \\
\hline Hazle et al. (16) & $\begin{array}{l}\text { Both the methods could predict the significant association between positive fluid balance and associated poor outcomes in infants } \\
\text { post-cardiac surgery }\end{array}$ \\
\hline Benoit et al. (17) & $\begin{array}{l}>10 \% \text { weight gain }(p=0.001) \text { and fluid overload }(0.075) \text { predicted PICU admission in pediatric stem cell transplant recipients on } \\
\text { univariate analysis but only }>10 \% \text { weight gain }(0.018) \text { remained an independent risk factor for PICU admission after adjustment }\end{array}$ \\
\hline Bontant et al. (18) & $\begin{array}{l}\text { - Correlations were strong between fluid input minus output/adjusted fluid input minus output and body weight change } \\
\text { - Agreement between was poor between fluid input minus output/adjusted fluid input minus output and body weight change during } \\
\text { the first } 24 \mathrm{~h} \text { after PICU admission } \\
\text { - Since daily body weight is not particularly difficult to measure, fluid input minus output/adjusted fluid input minus output } \\
\text { calculations may be reserved for the most severely ill patients in whom body weight measurement is strictly contraindicated }\end{array}$ \\
\hline Perren et al. (19) & $\begin{array}{l}\text { Correlation and Bland Altman agreement was poor between - body weight change and cumulative fluid balance in a cohort of ICU } \\
\text { patients }\end{array}$ \\
\hline Mank et al. (20) & $\begin{array}{l}\text { - Body weight was deemed to be a more accurate, safe and reliable parameter for monitoring fluid retention in patients undergoing } \\
\text { hyperhydration prior to chemotherapy } \\
\text { - Correlation between body weight change and cumulative fluid balance was relatively low }\end{array}$ \\
\hline Eastwood (21) & Body weight gain in post-cardiac surgery patients was falsely undermined by the fluid balance method \\
\hline Kelm et al. (22) & Fluid balance did not correlate with clinical and radiological evidence of FO in a large cohort of septic patients but body weight did \\
\hline \multicolumn{2}{|c|}{ FB method: $\% F O=\frac{(\text { daily fluid intake }(L)-\text { total output }(L))}{\text { Baseline body weight }(\mathrm{kg})} \times 100$} \\
\hline \multicolumn{2}{|c|}{$\begin{array}{l}\text { Or } \\
\% F O=\frac{(\text { CRRT initiation weight }(\mathrm{kg})-I \text { CUadmission weight }(\mathrm{kg}))}{\text { ICUadmission weight }(\mathrm{kg})} \times 100 .\end{array}$} \\
\hline
\end{tabular}


Damage to glycocalyx (sepsis,surgery, ischemia,hyperglycemia)

$\downarrow$

Loss of fluid from the vascular space

$\downarrow$

$\uparrow$ vascular capacitance

$\downarrow$

Overt hypovolemia

$\downarrow$

Injudicious fluid replacement

$\downarrow$

FLUID OVERLOAD

$\downarrow$

Raised capillary hydrostatic pressure

$\downarrow$

Loss of fluid into the interstitium

$\downarrow$

Impaired perfusion $\quad \longleftarrow \quad$ Organ edema

$\hat{\uparrow}$ Delirium, $\downarrow$ cognition

$\downarrow$ oxygenation, pleural effusions

$\downarrow$ myocardial contractility

$\downarrow \mathrm{CO}-[$ IAH, Ileus, cholestasis

$\downarrow$ wound healing, wound infections $\uparrow$ Renal venous pressure

$\downarrow$

$\uparrow$ Renal plasma flow

$\downarrow$

Reduced GFR

$\downarrow$

AKI

$\downarrow$

Oliguria

FIGURE 2 | Fluid overload: pathogenesis and detrimental effects. CO, Cardiac output; AKI, acute kidney injury; IAH, Intra-abdominal hypertension; GFR, Glomerular filtration rate.

odds for mortality (aOR 1.03) after controlling for the severity of illness, with the maximum risk noted in the cohort with $>20 \%$ FO(aOR 8.5,95\% CI 2.8-25.7). The RENAL study (Randomized Evaluation of Normal vs. Augmented Levels of renal replacement therapy) showed that a negative mean daily FB was significantly associated with reduced mortality $(p<0.0001)$ and increased RRT-free days ( $p=0.0017$ ) (46). Non- surviving CRRT recipients $(n=610)$ in the PICARD study also had a significantly higher $\%$ FO at CRRT initiation $(p=0.01)$ and cessation $(p=0.004)$ (47). A subsequent re-analysis highlighted for the first time an increased risk of sepsis in patients after AKI. Authors speculated that FO compromises epithelial integrity by causing gut edema, thus favoring bacterial translocation (48).

\section{Extracorporeal Membrane Oxygenation}

Patients on ECMO are vulnerable to develop significant degree of FO due to the inflammatory milieu triggered by their critical illness, exposure to extracorporeal circuit and iatrogenic administration of fluids to minimize venous access insufficiency. The association between FO and mortality in children on ECMO has been reaffirmed in various pediatric and adult cohorts. Per literature, the need for initiating RRT arises in almost $50 \%$ ECMO patients $(49,50)$. Selewski et al. recently showed that median FO at CRRT initiation and discontinuation were significantly lower in ECMO survivors (49). FO reduction to $<10 \%$ at CRRT conclusion was not associated with improved survival, emphasizing that early intervention is the key to 
enhanced survival. Although a growing body of evidence favors concomitant use of CRRT in ECMO patients, reports on this issue have been contentious $(51,52)$. In another study, Selewski showed that the degree of peak FO was associated with significant increases in duration of ECMO. Patients who died during hospitalization had higher FO at ECMO initiation, along with higher peak FO. Also noted was a graded increase in both ECMO and hospital mortality by $10 \%$ interval increases in FO (Table 4) (40).

\section{Cardiac Surgery}

In neonates with congenital heart disease undergoing cardiac surgery, fluid management is of particular importance. These patients are administered large amounts of fluid pre, intra, and post-operatively to prevent hypotension. The mainstay of management in these patients is diuretic therapy, with furosemide being the most widely administered drug (16). FO in these patients can also result from AKI (incidence $=30-50 \%$ ) and systemic inflammation stemming from cardiopulmonary bypass (CPB) (53). FO in this cohort is significantly associated with increased in-hospital mortality $(15,54,55)$; longer ICU and hospital stay, prolonged inotrope and ventilator support, and delayed sternal closure (56-59). Novel FO mitigating strategies, namely passive peritoneal drainage and modified ultrafiltration techniques are increasingly being employed. Given the high risk status of CHD patients, many are considered for preventative use of PD to reduce fluid accumulation. In some institutions the practice of inserting PD catheters intra-operatively is considered routine (16). Several studies have purported that prophylactic PD (peritoneal dialysis) achieves a net negative $\mathrm{FB}$, ameliorates post$\mathrm{CPB}$ inflammation via cytokine removal and reduces inotrope requirement (60-62). However, few single center studies do not reaffirm above findings (63). Most recent data on this population suggests that the potentially deleterious FO cut-off is likely $<10 \%$ as studies have demonstrated equally poor outcomes with a FO level as low as $5 \%(54,59)$.

\section{Neonates}

Association between FO and BPD (bronchopulmonary dysplasia) has been an active area of research. Studies document an association between FB and weight loss in the first few weeks of life and subsequent development of BPD in preterm neonates (64-66). In the neonatal period, a physiologic contraction of the extracellular fluid compartment leads to post-natal weight loss and a negative fluid and sodium balance. When this process is hindered by excess fluid intake, the retention of extracellular fluid can lead to fluid accumulation in pulmonary interstitial tissue. This puts the neonate at risk of barotrauma leading to BPD (64). Askenazi et al. reported that neonates with AKI had a higher maximum weight change in first 4 days of life $(p=0.05)$, higher risk of death and were more likely to require prolonged $\mathrm{MV}$ $(p<0.03)$ and oxygen support than neonates without AKI even post-adjustment (67). These studies suggest that ameliorating FO and AKI can reduce mortality and their sequelae (BPD and chronic kidney disease) which incur long term morbidity and excessive medical costs (Tables 3, 4). In the treatment of BPD, diuretics have been used; though studies have only shown short term effects without any long term benefits (80). Literature has suggested the possible benefit of practicing fluid restriction in preterm infants to prevent BPD. However, recent systematic review showed no evidence that supported fluid restriction in infants would prevent the subsequent development of BPD (81).

\section{Acute Respiratory Distress Syndrome}

Several studies have demonstrated association between FO and worse respiratory outcomes (72-74). The adult FACTT trial showed that mean CFB ( $p<0.001)$, VFDs (ventilator-free days) and ICU-free days were significantly lower in the conservative arm (31). Similarly, Valentine et al. noted that daily FO on D13 and CFB on D1-7 were higher in children with FO compared to adults in FACTT conservative arm ( $p<0.001$, each day) but similar to adults in the liberal arm, and promulgated the use of a Bayesian pediatric trial mirroring FACTT. No association with mortality was noted (73). A simplified fluid restrictive strategy employed in "FACTT lite" study also led to significantly lower FO than FACTT liberal protocol and no difference in VFDs compared to FACTT conservative protocol (82). Interestingly, mortality has been shown to correlate with increasing CFB (46), but not to a restrictive fluid management $(31,82)$.

\section{USE OF EARLY GOAL DIRECTED RESUSCITATION- HAS THE IMPASSE ENDED?}

The early goal directed therapy (EGDT) has been an area of intense research since its inception in the landmark Rivers' study wherein a mortality benefit was sought using protocolized (maintaining a CVP of $8-12 \mathrm{mmHg}$ and $\mathrm{SvO}_{2} \geq 70 \%$ ) fluid resuscitation within first $6 \mathrm{~h}$ in the treatment of septic patients (83). An early up-front aggressive resuscitation was effective but late and excessive fluid administration was associated with worse survival at hospital discharge, 28 and 60 days. The critical difference emphasized by this protocol was the timing of the administration since the overall amount of fluid administered was equal in the two groups: a corollary to the conclusions drawn by Arikan et al., who recently evaluated outcomes in a controlled before and after study using a protocol driven resuscitation bundle in children with septic shock (84). Even though the total volume of fluid boluses did not differ between the two groups, thoughtful fluid administration earlier during the course of illness decreased mortality, AKI incidence, and need for RRT in comparison to historical controls. This time-sensitive nature of shock resuscitation has been stressed upon many times due to evidence of higher mortality in children with a delay in reversal of shock (85-88).

A number of studies, however, have questioned the efficacy of EGDT. Three multicenter RCTs- ProCESS, ProMISE and ARISE, did not show a statistically significant reduction in 90d mortality with EGDT but reported mortality was lower than the anticipated rate (89-91). Current surviving sepsis campaign guidelines (SSCG) do not endorse EGDT but still permit the use of previous targets as no harm was documented in these trials (92). Subsequent meta-analyses have yielded inconclusive results 
TABLE 3 | Impact of FO on various outcome variables in the given pediatric populations.

\begin{tabular}{lll}
\hline Author; Year & $\begin{array}{l}\text { Outcome measures } \\
\text { considered }\end{array}$ & Observations
\end{tabular}

\section{RENAL REPLACEMENT THERAPY}

Sutherland et al. (41)

Mortality

Hayes et al. (42)

Gillespie et al. (44)

Foland et al. (45)

Goldstein et al. (12)

Mortality

Mortality

Mortality

Mortality

Mortality
Goldstein et al. (43)

FO at CRRT initiation with raised odds [aOR 1.03] for mortality [ $\geq 20,10-20,<10 \%$ FO groups with 65,43 , and $29 \%$ mortality respectively].

Median FO at CRRT initiation was $7.3 \%$ in survivors vs. $22.3 \%$ in non-survivors.

Mean FO at CRRT initiation was $25.4 \%$ in survivors vs. $14.2 \%$ in non-survivors.

$\geq 10 \% \mathrm{FO}$ at CRRT initiation significantly increased the risk of mortality [HR 3.02, 95\% Cl 1.5-6.1; $p=0.002]$

Median FO was significantly lower in survivors vs. non-survivors [7.8 vs. $15.5 \% ; p=0.01]$.

Mean FO was significantly lower in survivors [16.4\%] than non-survivors [34\%] after controlling for illness severity $[p=0.03]$.

\section{EXTRACORPOREAL MEMBRANE OXYGENATION}

Selewski et al. (49) Mortality

Median FO at CRRT initiation significantly lower in survivors compared to non-survivors [24.5 vs.

$38 \%, p=0.006]$.

$\mathrm{FO}<10 \%$ at CRRT initiation was associated with reduced odds of mortality [aOR $0.02,95 \% \mathrm{Cl}$ 0.00-0.07, $p=0.035]$.

Swaniker et al. (68) Mortality

Selewski et al. (40) Mortality

\section{CARDIAC SURGERY}

Lex et al. (54)

Mortality, LCOS, LMV

Sampaio et al. (56)

LMV, LOS

Piggottv et al. (57)

LOS, LMV, mortality

Seguin et al. (58) LOS, LMV, OI

Hassinger et al. (59)

LOS, LMV, inotropic support, AKI

Hazlev et al. (16)

LOS, LMV, mortality

Basu et al. (29)

AKI

Grist et al. (55)

Mortality, LOS

\section{NEONATES}

Lee and Cho (69)

Askenazi et al. (67)

Mortality

AKI

Askenazi et al. (70)

MV/death, AKI

Mean BW decreased about $5 \pm 2 \%$ in survivors vs. increasing $11 \pm 5 \%[p<0.001]$ in non-survivors.

Increased ECMO mortality was associated with >20\% FO at ECMO initiation (35.2 vs. 22\%;

$p=0.0003)$.

During ECMO, a peak FO > 30\% was associated with increased ECMO mortality (34 vs. 15.9\%; $p<0.0001)$.

$>5 \%$ FO was independently associated with mortality [aOR, 1.14,95\% Cl 1.008-1.303; $p=0.041$ ] and LCOS [1.21,95\% Cl 1.12-1.30, $p=0.001]$.

Maximum cumulative fluid balance $[6.82 \%(I Q R$ 3.28-11.71)] was associated with duration of MV [adjusted $\beta$ coefficient $=0.53, \mathrm{Cl} 0.38-0.66, p<0.001$ ], LOS in PICU [Spearman's $\rho=0.45$, $p<0.001]$.

$>15 \%$ FO was associated with higher mortality [31\% vs. 0\%; $p<0.001$ ], greater median LOS and LMV [39 vs. 76 days, $p=0.03$ and 8 vs. 25 days, $p<0.001$ respectively].

Peak cumulative FO during day 2 predicted longer LOS [aHR 0.95, 95\% Cl 0.92-0.99, $p=0.009$ ], longer MV [aHR 0.97, 95\% Cl 0.94-0.99, $p=0.03]$.

$\geq 5 \% \mathrm{FO}$ was independently associated with prolonged need for MV, LOS, inotropic support $[p<0.001]$ and post CPB-AKI [ $p=0.023]$.

Higher mean max FO by both FB [12 \pm 10 vs. $6 \pm 4 \%, p=0.03$ ] and weight based [24 \pm 15 vs. 14 $\pm 8 \%, p=0.02]$ methods was associated with composite poor outcome.

Infants who developed AKI after surgery had higher fluid balance [148 $\pm 125 \mathrm{vs} .115 \pm 117 \mathrm{ml} / \mathrm{d}$, $p=0.016]$.

Mean positive balance in non-survivors was $18 \mathrm{ml} / \mathrm{kg}$. FO was associated with increased mortality [aOR1.73 (95\% Cl 1.01-2.96)] and longer LOS $[p<0.05]$.

Neonates with $\geq 30 \% \mathrm{FO}$ at the time of CRRT initiation had lower survival rates $[p=0.009]$.

Median weight gain at D3 of life was higher in the AKI vs. non AKI cohort [8.2\% IQR (4.4-21.6\%) vs. $-4 \%$ (IQR-6.5 to $0.0 \%)(p<0.001)]$.

Infants with AKI had lower survival rates than those without AKI [72 vs. $100 \%(p<0.02)]$. Infants with AKI [30\%] had a higher max\% weight change in the first 4 days of life $[p=0.05]$ and were at higher risk of death/MV at D28 [p $<0.03]$.

\section{RESPIRATORY TRACT DISEASE}

Ingelse et al. (71) LMV

Sinitsky et al. (72) OI, LMV

Willson et al. (32) Mortality, VFDs, OI
Higher D3 CFB was independently associated with prolonged LMV $[\beta=0.166, p=0.048]$.

FO\% had significant correlation with OI [Spearman $\rho 0.318 ; p<0.0001$ ] and invasive ventilation days [ $\rho 0.274 ; p<0.0001]$.

Mean CFB in non-survivors was significantly higher than survivors $\left[8.7 \pm 9.5 \mathrm{~L} / \mathrm{m}^{2}\right.$ vs. $1.2 \pm 2.4 \mathrm{~L} / \mathrm{m}^{2}$; $p<0.001]$.

Higher CFB was significantly associated with fewer VFDs $(p<0.001)$ and higher OI $[0.52$ point increase in OSI for each $L / \mathrm{m}^{2}$ increase in FB; $p=0.011$.

Higher CFB at D3 was independently associated with fewer VFDs $[p=0.02]$. 
TABLE 3 | Continued

\begin{tabular}{|c|c|c|}
\hline Author; Year & $\begin{array}{l}\text { Outcome measures } \\
\text { considered }\end{array}$ & Observations \\
\hline Arikan et al. (33) & $\begin{array}{l}\text { LMV, PICU and hospital } \\
\text { LOS }\end{array}$ & $\begin{array}{l}\geq 15 \% \text { FO were both independently associated with LMV }[p=0.004 \text { and } 0.01] \text {, PICU stay } \\
{[p=0.008 \text { and } 0.01] \text { and hospital LOS }[p=0.02 \text { and } 0.04] \text {. }} \\
\text { Peak total FO, OI and PELOD score in survivors and non-survivors were } 13.7 \pm 10.0 \text { vs. } 15.9 \pm \\
10.3(p=0.45) ; 16.6 \pm 17.6 \text { vs. } 31.5 \pm 29.6(p=0.05) \text { and } 18.2 \pm 7.6 \text { vs. } 20.9 \pm 9.5(p=0.01) \\
\text { respectively. }\end{array}$ \\
\hline Floriv et al. (74) & Mortality, VFDs & $\begin{array}{l}\text { Positive FB (in increments of } 10 \mathrm{~mL} / \mathrm{kg} / 24 \mathrm{~h} \text { ) was significantly associated with increased mortality } \\
\text { [OR1.08, } 95 \% \mathrm{Cl} 1.01-1.15, p=0.02] \text { and reduced VFDs [-0.21 }(-0.39 \text { to }-0.04), p=0.02]\end{array}$ \\
\hline \multicolumn{3}{|l|}{ SEPSIS } \\
\hline Abulebda et al. (37) & Mortality & Median CFB in non-survivors was $19.5 \%$ vs. $6.5 \%$ in survivors [ $p<0.001]$ \\
\hline Chen et al. (75) & Mortality & $\begin{array}{l}\text { Both early FO and PICU-acquired daily FO of }>5 \% \text { were associated with mortality [aOR } 1.20 ; \\
95 \% \mathrm{Cl} 1.08-1.33 ; p=0.001 ; n=202 \text { and } \mathrm{aOR}=5.47 \text { per log increase; } 95 \% \mathrm{Cl} 1.15-25.96 ; \\
p=0.032 ; n=154] \text {. } \\
\text { Median values of early and acquired daily } \mathrm{FO} \text { in survivors vs. non-survivors were } 0.62 \% \text { [ }-0.47 \text { to } \\
2.19] \text { vs. } 3.00 \% \text { [ }-0.23 \text { to } 5.28] \text { and } 0.27 \% \text { [ } 1.66 \text { to } 4.61 \text { ] vs. } 4.27 \% \text { [ } 2.74 \text { to } 6.56 \text { respectively. }\end{array}$ \\
\hline \multicolumn{3}{|l|}{ MISCELLANEOUS } \\
\hline Li et al. (34) & Mortality, AKI & $\begin{array}{l}\text { Early FO ( }>5 \% \text { in first } 24 \mathrm{~h}) \text { was independently associated with } \mathrm{AKI}(\mathrm{OR} 1.34, p<0.001) \text { and } \\
\text { mortality (OR } 1.36, p<0.001) \text {. } \\
\text { Incidence of AKI and mortality in children with early FO was } 18.8 \text { vs. } 4.2 \text { and } 15.6 \% \text { vs. } 2.6 \% \\
\text { respectively when compared to children with }<5 \% \mathrm{FO} \text {. }\end{array}$ \\
\hline Bhaskar et al. (76) & Mortality & $\begin{array}{l}\text { Early FO (>10\% in } 72 \mathrm{~h} \text { ) [aOR } 9.17,95 \% \mathrm{Cl} 2.22-55.57] \text {, its severity [aOR } 1.11,1.05-1.19] \text { and } \\
\text { duration [aOR 1.61, } 1.21-2.28 \text { ] independently predicted mortality. } \\
\text { Cases had significantly higher mortality than controls [ } 26 \text { vs. } 6 \% ; p=0.003 \text { ], even in the matched } \\
\text { analysis [37 vs. } 3 \% ; p=0.002 \text { ]. }\end{array}$ \\
\hline
\end{tabular}

LOS-length of stay; LMV-length of mechanical ventilation; LCOS-low cardiac output syndrome; VFD-ventilator free days; aOR-adjusted odd ratio; HR-hazard ratio.

and equipoise still exists (93). Nevertheless, recruitment of less sick patients, treatment crossover due to non-blinding, and early institution of aggressive antibiotic therapy could haves biased the results of these negative trials (94).

Workman and colleagues recently showed that compliance with SSCG was not associated with better outcomes compared with usual therapy, which was administered more slowly in the emergency department (95). Since all children were treated rapidly, they reported low morbidity and mortality, and underscored the importance of rapid recognition and treatment of septic shock.

\section{FLUIDS: TYPE IN CRITICALLY ILL CHILDREN?}

In children with diabetic ketoacidosis, NS (normal saline) is the preferred resuscitating fluid but development of significant hyperchloremic acidosis necessitates a switch to hypotonic fluids such as $1 / 2 \mathrm{NS}$ or more physiological choices with lower chloride but high sodium concentrations such as LR (lactated Ringer's), Hartmann's solution, or plasmalyte (96). In pediatric acute respiratory distress syndrome, the PALICC recommends monitoring and titrating fluid balance to maintain adequate intravascular volume, while aiming to prevent positive fluid balance (97). Mechanical ventilation in acute lung injury reduces the amount of maintenance fluids, so in these patients the preferred choice is a dextrose containing solution with NS (or one of the other more physiological solutions) at two-thirds of the maintenance rate that is used recommended for nonmechanically ventilated patients (96).

In cases of pediatric sepsis, different studies have shown varying and conflicting data on which fluids provide adequate resuscitation without increasing mortality. The SSCG recommend crystalloids as the initial resuscitation fluid of choice, with addition of albumin only if substantial amounts of crystalloids are required (98). However, UK investigators obtained outstanding results with use of albumin boluses in resuscitation of children with meningococcal septic shock (99). In an RCT, Maitland et al. demonstrated a mortality benefit in malarial septic shock with albumin when compared to crystalloids (100). Nevertheless, evidence strongly recommends against using hydroxyethyl starch in adults and children due to an acute increase in RRT and red cell transfusion requirement $(92,98)$.

In a recent large matched cohort study on pediatric sepsis, LR resuscitation was not associated with reduced mortality, AKI, or dialysis even when matched by fluid volume and proportionate LR utilization (101). Mortality increased with larger fluid volumes and decreased with a greater proportion of fluid given as LR, but there were no differences between LR and NS groups after matching within volume quartiles, by proportionate LR utilization, or in the separate matched analysis of LR-only patients. However, LR was preferentially used either as first-line fluid in patients with lower illness severity or as an adjunctive fluid in patients who received large amounts of fluid, and the matching algorithm was least effective in the most severely ill patients receiving the largest total fluid volumes. This 
TABLE 4 | Summary of the studies evaluating outcomes associated with fluid overload in different pediatric populations.

\begin{tabular}{|c|c|c|c|c|}
\hline Author; Year & Study design & $\begin{array}{l}\text { Study sample [ } \boldsymbol{n} \text {; age } \\
\text { group; inclusion criteria] }\end{array}$ & $\begin{array}{l}\text { Substantive evidence } \\
\text { (regarding association of) }\end{array}$ & Relevant findings \\
\hline \multicolumn{5}{|c|}{ RENAL REPLACEMENT THERAPY } \\
\hline $\begin{array}{l}\text { Goldstein et al. } \\
(12)\end{array}$ & $\begin{array}{l}\text { Retrospective observational } \\
\text { Single center } \\
\text { 1996-1998 }\end{array}$ & $\begin{array}{l}21 \text { children } \\
8.8 \pm 6.3 \text { y } \\
\text { PICU patients receiving } \\
\text { CWH } \pm D\end{array}$ & $\begin{array}{l}\% \mathrm{FO} \text { at } \mathrm{CWH} / \mathrm{D} \text { initiation } \\
\text { with poor outcomes in } \\
\text { critically ill children }\end{array}$ & $\begin{array}{l}\text { - FO\% was significantly lower in survivors }(16.4 \pm \\
13.8 \%) \text { than nonsurvivors }(34 \pm 21 \%) \text { after } \\
\text { controlling for illness severity }(p=0.03)\end{array}$ \\
\hline Foland et al. (45) & $\begin{array}{l}\text { Retrospective observational } \\
\text { Single center } \\
\text { 1997-2003 }\end{array}$ & $\begin{array}{l}113 \text { children } \\
9.6 \text { y }(2.5-14.3) \\
\text { ICU children receiving } \mathrm{CWH}\end{array}$ & $\begin{array}{l}\text { \%FO prior to CWH and } \\
\text { mortality }\end{array}$ & $\begin{array}{l}\text { - Median FO\% was significantly lower in survivors vs. } \\
\text { nonsurvivors [7.8 vs. } 15.5 \% ; p=0.01] \\
\text { - FO\% at CWH initiation was independently } \\
\text { associated with mortality in patients with } \geq 3 \\
\text { organ MODS ( } p=0.01 \text { ) }\end{array}$ \\
\hline Gillespie et al. (44) & $\begin{array}{l}\text { Retrospective observational } \\
\text { Single center } \\
\text { 1993-2002 }\end{array}$ & $\begin{array}{l}77 \text { children } \\
\leq 20 y \\
\text { Patients on } \mathrm{CWH}\end{array}$ & $\begin{array}{l}\% \mathrm{FO} \text { at the time of } \mathrm{CWH} \\
\text { initiation with mortality }\end{array}$ & $\begin{array}{l}\text { - High FO ( } \geq 10 \%) \text { at CRRT initiation significantly } \\
\text { increased the risk of mortality }[\mathrm{HR} 3.02,95 \% \mathrm{Cl} \\
\text { 1.5-6.1; } p=0.002]\end{array}$ \\
\hline $\begin{array}{l}\text { Goldstein et al. } \\
\text { (43) }\end{array}$ & $\begin{array}{l}\text { Prospective observational } \\
\text { (ppCRRT) } \\
\text { Multicenter }\end{array}$ & $\begin{array}{l}116 \text { children } \\
<18 \text { y } \\
\text { MODS patients on CRRT }\end{array}$ & $\begin{array}{l}\% \text { FO prior to CRRT initiation } \\
\text { with mortality in MODS } \\
\text { patients }\end{array}$ & $\begin{array}{l}\text { \%FO at CRRT initiation was significantly lower for } \\
\text { survivors than non-survivors even after adjusting for } \\
\text { severity of illness } \\
\text { Similar findings for patients receiving mechanical } \\
\text { ventilation and vasoactive pressors, even after } \\
\text { adjusting for illness severity }(p<0.05)\end{array}$ \\
\hline Hayes et al. (42) & $\begin{array}{l}\text { Retrospective observational } \\
\text { Single center } \\
\text { 2000-2005 }\end{array}$ & $\begin{array}{l}76 \text { children } \\
5.8 \text { y }(0-19) \\
\text { PICU patients with AKI } \\
\text { needing CRRT }\end{array}$ & $\begin{array}{l}\% \text { FO at CRRT initiation with } \\
\text { mortality }\end{array}$ & $\begin{array}{l}\text { - Median } \% \text { FO at CRRT initiation was } 7.3 \% \text { in } \\
\text { survivors vs. } 22.3 \% \text { in nonsurvivors }(p=0.0001) \\
\text { - } \geq 20 \% \text { FO at CRRT initiation was significantly } \\
\text { associated with mortality ( } p=0.006) \text {, LMV } \\
\text { ( } p=0.018) \text {, PICU stay ( } p=0.0425) \text {, hospital LOS } \\
(p=0.0123)\end{array}$ \\
\hline $\begin{array}{l}\text { Sutherland et al. } \\
(41)\end{array}$ & $\begin{array}{l}\text { Prospective observational } \\
\text { (ppCRRT) } \\
\text { Multicenter } \\
2001-2005\end{array}$ & $\begin{array}{l}297 \text { children } \\
<18 \text { y } \\
\text { ICU children on CRRT }\end{array}$ & $\begin{array}{l}\text { \%FO with mortality in } \\
\text { children receiving CRRT }\end{array}$ & $\begin{array}{l}\text { - FO of } \geq 20 \% \text { was independently associated with } \\
\text { increased mortality (aOR 8.5, 95\% Cl 2.8-25.7) } \\
\text { - Presence of FO at CRRT initiation was associated } \\
\text { with raised odds [aOR 1.03] for mortality which } \\
\text { was significantly higher for worse degrees of FO } \\
\text { [ } \geq 20,10-20,<10 \% \text { FO groups with } 65,43 \text { and } \\
29 \% \text { mortality respectively] }\end{array}$ \\
\hline Selewski et al. (49) & $\begin{array}{l}\text { Retrospective observational } \\
\text { Single center } \\
2006-2010\end{array}$ & $\begin{array}{l}113 \text { children } \\
19 \mathrm{~m}(0.2-181) \\
\text { PICU patients on CRRT }\end{array}$ & $\begin{array}{l}\text { Different weight based FO } \\
\text { definitions with PICU } \\
\text { mortality }\end{array}$ & $\begin{array}{l}\text { - FO\% at CRRT initiation was significantly greater } \\
\text { in non-survivors via both weight based and FB } \\
\text { method } \\
\text { - Univariate OR for PICU mortality was } 1.056 \text { [ } 95 \% \mathrm{Cl} \\
\text { 1.025-1.087] by fluid balance method, } 1.044 \text { [95\% } \\
\text { Cl 1.019-1.069] by the PICU admission weight- } \\
\text { based method and } 1.045 \text { [ } 95 \% \mathrm{Cl} 1.022-1.07] \text { by } \\
\text { hospital admission weight-based method } \\
\text { - On multivariate analyses, all three methods } \\
\text { significantly predicted PICU survival }\end{array}$ \\
\hline $\begin{array}{l}\text { de Galasso et al. } \\
\text { (38) }\end{array}$ & $\begin{array}{l}\text { Retrospective observational } \\
\text { Single center } \\
2000-2012\end{array}$ & $\begin{array}{l}131 \text { children } \\
0-18 \text { y } \\
\text { PICU patients on CRRT }\end{array}$ & $\begin{array}{l}\text { FO with mortality only in } \\
\text { children with milder disease }\end{array}$ & $\begin{array}{l}\text { - FO }>10 \% \text { at CRRT initiation was associated with } \\
\text { mortality only in children with milder disease [OR } \\
\text { 10.9,95\% } \% \text { Cl } 0.78-152.62 ; p=0.07 \text { ] }\end{array}$ \\
\hline \multicolumn{5}{|c|}{ EXTRACORPOREAL MEMBRANE OXYGENATION } \\
\hline Hoover et al. (77) & $\begin{array}{l}\text { Retrospective observational } \\
\text { (Matched case control) } \\
\text { 1992-2006 } \\
\text { Single center }\end{array}$ & $\begin{array}{l}86 \text { children } \\
1 \mathrm{~m}-18 \text { y } \\
\text { Patients on ECMO vs. those } \\
\text { on ECMO+CWH }\end{array}$ & $\begin{array}{l}\text { Improved fluid balance, } \\
\text { caloric intake and less } \\
\text { furosemide use with } \\
\text { ECMO+CWH cf ECMO } \\
\text { alone }\end{array}$ & $\begin{array}{l}\text { In ECMO survivors who received CWH, median FB } \\
\text { was less than that in non-CWH survivors [25.1 vs. } \\
40.2 \mathrm{ml} / \mathrm{kg} / \mathrm{d} ; p=0.028 \text { ] } \\
\text { - Use of } \mathrm{CWH} \text { was associated with earlier optimal } \\
\text { caloric intake ( } p<0.001 \text { ) and reduced diuretic } \\
\text { administration ( } p=0.009) \\
\text { - Survival did not differ significantly in the two } \\
\text { groups ( } p=0.51)\end{array}$ \\
\hline Blijdorp et al. (78) & $\begin{array}{l}\text { Retrospective observational } \\
\text { (1:3 matched case- } \\
\text { comparison) } \\
2002-2006 \\
\text { Single center }\end{array}$ & $\begin{array}{l}61 \text { neonates } \\
<28 \mathrm{~d} \\
\text { Patients on } \mathrm{ECMO} \text { vs. those } \\
\text { on } \mathrm{ECMO}+\mathrm{CWVH}\end{array}$ & $\begin{array}{l}\text { Better fluid balance via HF in } \\
\text { ECMO patients with } \\
\text { improved outcomes }\end{array}$ & $\begin{array}{l}\text { - Median time on ECMO [98h,IQR 48-187 vs. } \\
\text { 126h,24-403; } p=0.02 \text { ] and MV post } \\
\text { decannulation [2.5d vs. 4.8d; } p=0.04] \text { was } \\
\text { significantly shorter in HF group }\end{array}$ \\
\hline
\end{tabular}


TABLE 4 | Continued

\begin{tabular}{|c|c|c|c|}
\hline Author; Year & Study design & $\begin{array}{l}\text { Study sample [ } n \text {; age } \\
\text { group; inclusion criteria] }\end{array}$ & $\begin{array}{l}\text { Substantive evidence } \\
\text { (regarding association of) }\end{array}$ \\
\hline Paden (52) & $\begin{array}{l}\text { Retrospective observational } \\
\text { 1997-2007 } \\
\text { Single center }\end{array}$ & $\begin{array}{l}68 \text { children } \\
<19 \text { y } \\
\text { Patients on ECMO+CRRT }\end{array}$ & $\begin{array}{l}\text { Recovery of renal function } \\
\text { and survival with HF during } \\
\text { ECMO }\end{array}$ \\
\hline Selewski et al. (40) & $\begin{array}{l}\text { Retrospective cohort } \\
\text { Multicenter } \\
2007-2011\end{array}$ & $\begin{array}{l}756 \text { children } \\
<18 \text { y } \\
\text { Patients on ECMO }\end{array}$ & $\begin{array}{l}\text { Survival associated with } \\
\text { peak FO during ECMO and } \\
\% F O \text { at ECMO initiation }\end{array}$ \\
\hline
\end{tabular}

Relevant findings

- Cost per ECMO run and blood transfusion requirement was also reduced $(p<0.001)$

- No mortality benefit was noted in the HF group

- In the absence of primary renal disease, chronic renal failure did not occur following concurrent use of CRRT with ECMO

- Mortality is higher in patients receiving concomitant CRRT and ECMO compared to those receiving $\mathrm{ECMO}$, but is similar to patients requiring CRRT who are not on ECMO

- A significantly higher hospital mortality risk was associated with each $10 \%$ rise of $\mathrm{FO}$ at initiation of ECMO (OR, 1.12; 95\% Cl, 1.04-1.19 $p=0.002$ ).

- With each $10 \%$ rise in peak FO during ECMO, there was a $9 \%$ increased odds of ECMO mortality and a 17\% increased odds of hospital mortality

\section{CARDIAC SURGERY}

Grist et al. (55)

Retrospective observational Single center 2003-2009

Saini et al. (60)

Retrospective observational (1:1 matched case control) Single center 2006-2010

Hazle et al. (16) Prospective observational Single center 2009-2010

Sasser et al. (61) Prospective before and after nonrandomized cohort Single center 2010-2011

Basu et al. (29)

Retrospective observational Single center 1997-2008

Seguin et al. (58) Retrospective observational Single center 2005-2007

\section{0 children}

Underwent congenital heart surgery with $\mathrm{CPB}$ and MUF

36 infants

$<1 \mathrm{y}$

Post- atrioventricular septal defect repair $\pm P D$ insertion

49 infants

$<6 \mathrm{~m}$

Underwent congenital heart surgery

52 neonates and infants Underwent congenital cardiac surgery with (25) or without (27) prophylactic PD use

92 children

5.5 days (4-7.5)

Status post arterial switch operation

193 patients

$<18 y$

Post cardiac surgery
FO with mortality in children undergoing $\mathrm{CPB}$

Improved fluid balance with passive PD insertion post AVSD repair in infants

Postop FO with longer LOS, $\mathrm{MV}$ and mortality in infants undergoing cardiac surgery

Greater net negative FB with prophylactic PD placement post-CBP in infants

Delayed AKI diagnosis with unadjusted sCr (not accounting for positive FB)

Early FO with LOS, MV and OI
- 20\% (314) children had a positive FB

- Patients with positive FB weighed more, had higher RACHS score, longer pump time, longer LOS with an aOR for mortality of $1.73(95 \% \mathrm{Cl}$ 1.01-2.96)[ $p<0.05$ for all variables]

Infants with passive PD achieved negative fluid balance more rapidly $(12 \pm 10$ vs. $27.3 \pm 13 \mathrm{~h}$, $p<0.0001)$ and to a greater extent $(p=0.002)$

- Higher mean max FO by both FB (12 \pm 10 vs. $6 \pm 4 \%, p=0.03$ ) and weight based (24 \pm 15 vs. $14 \pm 8 \%, p=0.02$ ) methods was associated with composite poor outcome

- FO $<10 \%$ was associated with a good outcome by both FB and weight based methods $(p=0.02,0.01)$ but the association did not reach statistical significance after multivariate analysis

- Median net fluid balance was more negative in +PD at 24 and $48 \mathrm{~h}[-24 \mathrm{~mL} / \mathrm{kg}($ IQR-62,11) vs. +18 $(-26,11), p=0.003$;

- $88(-132,-54)$ vs. $-46(-84,-12), p=0.004]$

- Duration of MV $(p=0.1)$, mean inotrope score $(p=0.04)$ and serum IL-6 and 8 levels were lower in $+\mathrm{PD}$ at $24 \mathrm{~h}$

- Median time to sternal closure was lower in +PD [24 h (IQR 20-40) vs. 63 (44-72), $p<0.001]$

- Infants who developed AKI after surgery had higher POD1 FB $[148 \pm 125$ vs. $115 \pm 117 \mathrm{ml} / \mathrm{d}$, $p=0.016]$

- Correcting sCr for FO increased AKI prevalence and strengthened its association with postop morbidities

- Early postop fluid administration was independently associated with higher D2 FO\% $(p=0.0001)$

- D2 FO\% predicted longer LOS (aHR 0.95, 95\%Cl 0.92-0.99, $p=0.009$ ), longer MV (aHR 0.97, $95 \% \mathrm{Cl} 0.94-0.99, p=0.03$ )

- Higher daily FO\% predicted worse daily OI in patients without cyanotic heart disease (aHR $0.16,95 \% \mathrm{Cl} 0.07-0.25, p=0.03$ ) 
TABLE $4 \mid$ Continued

\begin{tabular}{|c|c|c|c|}
\hline Author; Year & Study design & $\begin{array}{l}\text { Study sample [ } \boldsymbol{n} \text {; age } \\
\text { group; inclusion criteria] }\end{array}$ & $\begin{array}{l}\text { Substantive evidence } \\
\text { (regarding association of }\end{array}$ \\
\hline $\begin{array}{l}\text { Hassinger et al. } \\
\text { (59) }\end{array}$ & $\begin{array}{l}\text { Secondary analysis of } \\
\text { prospective observational } \\
\text { study } \\
\text { Single center }\end{array}$ & $\begin{array}{l}98 \text { children } \\
2 \text { wks-18 y } \\
\text { Status post-CPB }\end{array}$ & $\begin{array}{l}\text { Early postop FO with } \\
\text { prolonged LOS , LMV, } \\
\text { inotropic support and AKI } \\
\text { development }\end{array}$ \\
\hline
\end{tabular}

Kwiatkowski et al. Retrospective observational (62) (1:1 matched case control) 2007-2012

Piggott et al. (57)

Retrospective observationa Single center 2010-2013

Sampaio et al. (56) Retrospective observational 2010-2013

Lex et al. (54)
84 infants

$<6 \mathrm{~m}$ surgery \pm PDC insertion

95 neonates

6-29 d

Underwent congenital cardiac surgery
Underwent congenital heart

Postop FO with prolonged MV, LOS and mortality

Improved FB via elective PDC use with favorable outcomes in infants undergoing cardiac surgery

with prolonged $\mathrm{MV}$ and LOS in patients post-congenital heart surgery Surgery for congen disease+ MV for at least $12 \mathrm{~h}$ in PICU

\section{1,520 children}

$<18$ y

Underwent open heart surgery

Early postop FO with higher mortality and morbidity

\section{Relevant findings}

- Early postop FO ( $\geq 5 \%$ ) was independently associated with prolonged need for MV, LOS and inotropic support $(p<0.001)$

- FO was associated with post-CPB AKI; FO more often preceded than followed it but AKI was not consisitently associated with FO

- Cumulative fluid administered was an excellent predictor of modified PRIFLE category [AUC $=0.96,95 \% \mathrm{Cl} 0.92-1,-p=0.002$ ]

- Patients with FO were administered higher fluid volume $(p<0.001)$ and had a poor urinary response to diuretics

- PDC+ group had higher negative fluid balance on POD 1 and 2 (57 vs. $33 \%, p<0.04 ; 85$ vs. $61 \%$, $p<0.01)$

- PDC+ group had shorter time to negative FB (16 vs. $32 \mathrm{~h}, p<0.0001$ ), earlier extubation (80 vs. $104 \mathrm{~h}, p<0.02)$, improved inotrope scores $(p<0.04)$, and fewer electrolyte imbalances requiring correction $(p<0.03)$

- AKI in $45 \%$ neonates

- $>15 \%$ FO was associated with prolonged LOS $(p=0.03)$, postop ventilator days $(p<0.001)$ and mortality $(p<0.001)$

- Certain risk factors like preop aminoglycoside use, selective cerebral perfusion, CPB time, small kidneys on US can be modified to minimize risk of $\mathrm{AKI}$ and perhaps FO

- Prophylactic PD catheters can be placed in infants with small kidneys identified preoperatively to avert FO

- Maximum CFB was associated with duration of MV (adjusted $\beta$ coefficient $=0.53, \mathrm{Cl} 0.38-0.66$, $P<0.001$ ), LOS in PICU (Spearman's $\rho=0.45$, $P<0.001)$, and presence of chest wall edema and pleural effusions on chest radiograph $(p=0.003)$ associated with mortality (aOR, 1.14,95\% Cl 1.008-
Secondary analysis of a prospective observational study Single center 2004-2008
Higher FO on the day of surgery was independently $1.303 ; p=0.041)$ and $\operatorname{LCOS}(1.21,95 \% \mathrm{Cl} 1.12-$ $1.30, p=0.001)$

- Higher maximum s.Cr (aOR 1.01,1.003-1.021; $p=0.009$ ), maximum vasoactive-inotropic score (aOR 1.01,95\% Cl 0.005-1.029; $p=0.042$ ) and higher blood loss on the day of the surgery (aOR1.01, 95\%Cl 1.004-1.025; $p=0.015$ ) were associated with a higher risk of $>5 \% \mathrm{FO}$

\section{NEONATES}

Ohv et al. (64)
Secondary analysis of the RCT by the Neonatal Research Network Multicenter 1999-2001
1,382 neonates

ELBW newborns with birth wt between 401 and $1,000 \mathrm{~g}$
Positive FB in the first 10 days of life with death/BPD
- 58\% either died or developed BPD; 42\% survived without BPD

- Higher fluid intake $(p<0.001)$ or lower weight loss $(p=0.06)$ during first $10 \mathrm{~d}$ were significantly associated with death/BPD

- Lower BW/GA/1.5 min Apgar scores, higher $\mathrm{O}_{2}$ requirement at $24 \mathrm{~h}$ of life and longer $\mathrm{LMV}$ were associated with death/BPD 
TABLE 4 | Continued

\begin{tabular}{|c|c|c|c|c|}
\hline Author; Year & Study design & $\begin{array}{l}\text { Study sample [ } \boldsymbol{n} ; \text { age } \\
\text { group; inclusion criteria] }\end{array}$ & $\begin{array}{l}\text { Substantive evidence } \\
\text { (regarding association of) }\end{array}$ & Relevant findings \\
\hline Schmidt et al. (65) & $\begin{array}{l}\text { Secondary analysis of TIPP } \\
\text { (Randomized controlled trial } \\
\text { of Indomethacin prophylaxis } \\
\text { in preterms) } \\
\text { Multicenter }\end{array}$ & $\begin{array}{l}999 \text { neonates } \\
\text { Extremely low birth weight } \\
\text { newborns who survived to a } \\
\text { postmenstrual age of } 36 \\
\text { wks }\end{array}$ & $\begin{array}{l}\text { - Positive FB in preemies } \\
\text { with subsequent BPD } \\
\text { - Uncertainty about } \\
\text { cause-and-effect } \\
\text { relationship between PDA } \\
\text { and BPD }\end{array}$ & $\begin{array}{l}\text { - Neonates without PDA who received prophylactic } \\
\text { indomethacin had lower urinary output, lower } \\
\text { weight loss }(p=0.012) \text { and higher } \mathrm{FiO}_{2} \\
\text { requirement }(p<0.0001) \text { by the end of first } \\
\text { week } \\
\text { - Incidence of BPD was similar in PDA+ neonates } \\
\text { irrespective of indomethacin prophylaxis but was } \\
\text { significantly higher in PDA- infants who received } \\
\text { indomethacin ( } p=0.015) \\
\text { - Indomethacin prophylaxis reduces the incidence } \\
\text { of PDA but not that of BPD }\end{array}$ \\
\hline Askenazi et al. (70) & $\begin{array}{l}\text { Prospective observational } \\
\text { Single center } \\
2010-2011\end{array}$ & $\begin{array}{l}58 \text { neonates } \\
\text { near term ( } \geq 34 \text { wks and } \\
>2,000 \mathrm{~g}) \text { and term with } \\
\text { Apgar score } \leq 7\end{array}$ & $\begin{array}{l}\text { AKI with FO and mortality in } \\
\text { sick near term/term } \\
\text { neonates }\end{array}$ & $\begin{array}{l}\text { - AKI in } 15.6 \% \text { neonates } \\
\text { - Median weight gain at D3 of life was higher in the } \\
\text { AKI vs. non AKI cohort [8.2\%, IQR 4.4-21.6\% vs. } \\
-4 \%, I Q R-6.5 \text { to } 0.0 \%(p<0.001)] \\
\text { - Infants with AKI had lower survival rates than } \\
\text { those without AKI }[72 \% \text { vs. } 100 \%(p<0.02)]\end{array}$ \\
\hline Askenazi et al. (67) & $\begin{array}{l}\text { Prospective observational } \\
\text { Single center } \\
2012-2013\end{array}$ & $\begin{array}{l}122 \text { preterm neonates } \\
<31 \mathrm{wks},<1,200 \mathrm{~g}\end{array}$ & $\begin{array}{l}\text { - FO with prolonged need } \\
\text { for oxygen support, MV } \\
\text { and mortality } \\
\text { - AKI with BPD and } \\
\text { mortality }\end{array}$ & $\begin{array}{l}\text { - Infants with } \mathrm{AKI}(30 \%) \text { had a higher max } \% \text { wt } \\
\text { change in the first } 4 \text { days of life }(p=0.05) \text { and were } \\
\text { at higher risk of death/MV at D28 }(p<0.03) \\
\text { - Although infants with FO had an increased RR to } \\
\text { receive oxygen support/death }(1.02,95 \% \mathrm{Cl} 1.01- \\
\text { 1.03; } p<0.0001) \text { and } \mathrm{MV} / \text { death }(1.03,1.02-1.05 \text {; } \\
p<0.0001) \text { at D28, after adjustment this trend did } \\
\text { not reach statistical significance }(p=0.16,0.06) \\
\text { - Similar finding was noted for time taken to oxygen } \\
\text { weaning }[\mathrm{HR} 0.97(0.9-0.99), p<0.02 ; \text { aHR } 0.98 \\
\text { (0.9-1.01), } p=0.18]\end{array}$ \\
\hline Lee and Cho (69) & $\begin{array}{l}\text { Retrospective observational } \\
\text { Single center } \\
200-2014\end{array}$ & $\begin{array}{l}34 \text { neonates ( } 15 \text { preterm, } \\
19 \text { term) } \\
\text { Admitted to NICU } \\
\text { On CRRT for } \geq 24 \mathrm{~h}\end{array}$ & $\begin{array}{l}\text { Higher \%FO at CRRT } \\
\text { initiation with mortality }\end{array}$ & $\begin{array}{l}\text { - Neonates with } \geq 30 \% \text { FO at the time of CRRT } \\
\text { initiation had lower survival rates } \\
\text { - Univariate Cox regression analysis revealed that a } \\
\text { higher \%FO at CRRT initiation and decreased urine } \\
\text { output at the end of CRRT were associated with } \\
\text { mortality } \\
\text { - Multivariate Cox regression analysis showed that } \\
\text { decreased urine output at CRRT conclusion was } \\
\text { associated with mortality }\end{array}$ \\
\hline \multicolumn{5}{|c|}{ RESPIRATORY TRACT DISEASE } \\
\hline Sinitsky et al. (72) & $\begin{array}{l}\text { Retrospective observational } \\
\text { Single center } \\
\text { 2009-2013 }\end{array}$ & $\begin{array}{l}636 \text { children } \\
<16 \text { y } \\
\text { Mechanically ventilated } \\
\text { PICU patients }\end{array}$ & $\begin{array}{l}\text { Early FO with respiratory } \\
\text { morbidity in PICU patients }\end{array}$ & $\begin{array}{l}\text { - FO\% had significant correlation with OI [Spearman } \\
\rho 0.318 ; p<0.0001] \text { and invasive ventilation days } \\
{[\rho 0.274 ; p<0.0001]} \\
\text { - FO\% at } 48 \mathrm{~h} \text { was significant predictor of both OI } \\
\text { ( } p<0.001) \text { and ventilation days }(p=0.002) \\
\text { - No association of FO\% at } 48 \mathrm{~h} \text { with mortality }\end{array}$ \\
\hline Flori et al. (74) & $\begin{array}{l}\text { Post hoc analysis of a } \\
\text { prospective observational } \\
\text { study } \\
\text { Multicenter 1996-2000 }\end{array}$ & $\begin{array}{l}320 \text { children } \\
<18 \text { y } \\
\text { Mechanically ventilated } \\
\text { patients with ALI }\end{array}$ & $\begin{array}{l}\text { FO with mortality and } \\
\text { respiratory morbidity in } \\
\text { children with ALI }\end{array}$ & $\begin{array}{l}\text { - Positive FB (in increments of } 10 \mathrm{~mL} / \mathrm{kg} / 24 \mathrm{~h} \text { ) was } \\
\text { significantly associated with increased mortality } \\
\text { [OR1.08, } 95 \% \mathrm{Cl} 1.01-1.15, p=0.02] \text { and } \\
\text { reduced VFDs [-0.21 (-0.39 to }-0.04 \text { ), } \\
p=0.02] \text {, even after adjusting for multiple organ } \\
\text { system failure, sepsis and the extent of } \\
\text { oxygenation defect }\end{array}$ \\
\hline Valentine et al. (73) & $\begin{array}{l}\text { Retrospective observational } \\
\text { Multicenter } \\
2007-2010\end{array}$ & $\begin{array}{l}168 \text { children } \\
1 \mathrm{~m}-18 \mathrm{y} \\
\text { Mechanically ventilated } \\
\text { patients with ALI }\end{array}$ & $\begin{array}{l}\text { FO with fewer VFDs in } \\
\text { children with ALI }\end{array}$ & $\begin{array}{l}\text { - Higher CFB at D3 was independently associated } \\
\text { with fewer VFDs }(p=0.02) \\
\text { - No association with mortality was noted }(p=0.11)\end{array}$ \\
\hline
\end{tabular}


TABLE 4 | Continued

\begin{tabular}{|c|c|c|c|c|}
\hline Author; Year & Study design & $\begin{array}{l}\text { Study sample [ } \boldsymbol{n} \text {; age } \\
\text { group; inclusion criteria] }\end{array}$ & $\begin{array}{l}\text { Substantive evidence } \\
\text { (regarding association of) }\end{array}$ & Relevant findings \\
\hline Ingelse et al. (71) & $\begin{array}{l}\text { Retrospective observational } \\
\text { Single center } \\
2008-2014\end{array}$ & $\begin{array}{l}135 \text { children } \\
<2 \text { y } \\
\text { Mechanically ventilated } \\
\text { PICU patients with viral } \\
\text { lower respiratory tract } \\
\text { disease }\end{array}$ & $\begin{array}{l}\text { Early FO with prolonged } \\
\text { LMV }\end{array}$ & $\begin{array}{l}\text { - Mean CFB on D3 was } 97.9 \pm 49.2 \mathrm{~mL} / \mathrm{kg} \\
\text { - Higher D3 CFB was independently } \\
\text { associated with prolonged LMV } \\
{[\beta=0.166, p=0.048]} \\
\text { - No association found Between D3 CFB and sOSI } \\
\quad(p=0.7)\end{array}$ \\
\hline Willson et al. (32) & $\begin{array}{l}\text { Post hoc analysis of the } \\
\text { pediatric arm of an RCT } \\
\text { Multicenter } \\
2008-2010\end{array}$ & $\begin{array}{l}110 \text { children } \\
0-18 \text { y } \\
\text { Mechanically ventilated } \\
\text { children with ALI }\end{array}$ & $\begin{array}{l}\text { FO with mortality, fewer } \\
\text { VFDs and worse } \\
\text { oxygenation }\end{array}$ & $\begin{array}{l}\text { - Mean CFB in non-survivors was significantly higher } \\
\text { than survivors }\left[8.7 \pm 9.5 \text { vs. } 1.2 \pm 2.4 \mathrm{~L} / \mathrm{m}^{2} \text {; }\right. \\
p<0.001] \\
\text { - Higher CFB was significantly associated with } \\
\text { fewer VFDs }(p<0.001) \text { and higher OI }[0.52 \text { point } \\
\text { increase in OSI for each } \mathrm{L} / \mathrm{m}^{2} \text { increase in FB; } \\
p=0.011]\end{array}$ \\
\hline Arikan et al. (33) & $\begin{array}{l}\text { Retrospective observational } \\
\text { Single center } \\
2004-2005\end{array}$ & $\begin{array}{l}80 \text { children } \\
59 \pm 73 \text { months (mean } \pm \\
S D \text { ) } \\
\text { Mechanical ventilation for } \\
24 \mathrm{~h} \text { and presence of an } \\
\text { indwelling arterial catheter }\end{array}$ & $\begin{array}{l}\text { FO with prolonged LOS, } \\
\text { LMV and impaired } \\
\text { oxygenation }\end{array}$ & $\begin{array}{l}\text { - Higher peak FO\% predicted higher peak OI, } \\
\text { independent of age, gender and PELOD scores } \\
\text { ( } p<0.009) \\
\text { - Peak FO\% and severe FO } \%(\geq 15 \%) \text { were both } \\
\text { independently associated with prolonged LMV } \\
\text { ( } p=0.004 \text { and } 0.01) \text {, PICU stay }(p=0.008 \text { and } \\
0.01) \text { and hospital LOS ( } p=0.02 \text { and } 0.04)\end{array}$ \\
\hline \multicolumn{5}{|l|}{ SEPSIS } \\
\hline $\begin{array}{l}\text { Abulebda et al. } \\
\text { (37) }\end{array}$ & $\begin{array}{l}\text { Retrospective observational } \\
\text { Multicenter }\end{array}$ & $\begin{array}{l}317 \text { children } \\
<10 \text { y } \\
\text { Septic shock patients }\end{array}$ & $\begin{array}{l}\text { FO with mortality only in low } \\
\text { risk septic patients, barring } \\
\text { the intermediate and high } \\
\text { risk cohort }\end{array}$ & $\begin{array}{l}\text { - Increased CFB was associated with mortality in the } \\
\text { low risk cohort ( } n=204, \mathrm{OR} 1.035,95 \% \mathrm{Cl} 1.004- \\
\text { 1.066) but not in the intermediate and high risk } \\
\text { cohorts } \\
\text { - Higher FB in the first } 24 \mathrm{~h} \text { was not associated with } \\
\text { mortality }\end{array}$ \\
\hline Chen et al. (75) & $\begin{array}{l}\text { Retrospective observational } \\
\text { Single center } \\
2011-2015\end{array}$ & $\begin{array}{l}202 \text { children } \\
1 \mathrm{~m}-18 \text { y } \\
\text { Admitted to PICU with } \\
\text { severe sepsis }\end{array}$ & $\begin{array}{l}\text { Early and acquired daily FO } \\
\text { with mortality in septic } \\
\text { children }\end{array}$ & $\begin{array}{l}\text { Both early FO (aOR 1.20; 95\%Cl 1.08-1.33; } p \\
=0.001 ; n=202) \text { and } \mathrm{PICU}-\mathrm{acquired} \text { daily FO } \\
\text { (aOR }=5.47 \text { per log increase; } 95 \% \mathrm{Cl} 1.15-25.96 ; \\
p=0.032 ; n=154 \text { ) were independent risk factors } \\
\text { associated with mortality even after adjusting for } \\
\text { illness severity } \\
\text { - Median PICU LOS increased with greater } \\
\text { fluctuations in FO }[p<0.001] \\
\text { - Early FO achieved an AUC of } 0.74(95 \% \mathrm{Cl} \\
\text { 0.65-I0.82; } p=<0.001 ; n=202) \text { for predicting } \\
\text { mortality }\end{array}$ \\
\hline \multicolumn{5}{|c|}{ MISCELLANEOUS } \\
\hline Bhaskar et al. (76) & $\begin{array}{l}\text { Retrospective observational } \\
\text { (Matched case-control) } \\
\text { Single center } \\
\text { 2009-2010 }\end{array}$ & $\begin{array}{l}114 \text { children } \\
0-17.4 \text { y } \\
\text { Admitted to PICU with } \\
\text { shock }\end{array}$ & $\begin{array}{l}\text { Early FO with mortality in } \\
\text { shock patients }\end{array}$ & $\begin{array}{l}\text { Early } \mathrm{FO}(>10 \% \text { in } 72 \mathrm{~h})[\mathrm{aOR} 9.17,95 \% \mathrm{Cl} \\
2.22-55.57] \text {, its severity }[\mathrm{aOR} 1.11,1.05-1.19] \text { and } \\
\text { duration [aOR 1.61, 1.21-2.28] as independent } \\
\text { predictors of mortality } \\
\text { - Cases had significantly higher mortality than } \\
\text { controls ( } 26 \text { vs. } 6 \% ; p=0.003) \text {, even in the } \\
\text { matched analysis ( } 37 \text { vs. } 3 \% ; p=0.002)\end{array}$ \\
\hline Liv et al. (34) & $\begin{array}{l}\text { Prospective observational } \\
\text { Single center } \\
2011-2012\end{array}$ & $\begin{array}{l}320 \text { children } \\
1 \mathrm{~m}-16 \text { y } \\
\text { Admitted to PICU for }>24 \mathrm{~h}\end{array}$ & $\begin{array}{l}\text { Early FO with AKI and } \\
\text { mortality in critically ill } \\
\text { children }\end{array}$ & $\begin{array}{l}\text { - Early FO was independently associated with AKI } \\
\text { (OR 1.34, } p<0.001) \text { and mortality (OR } 1.36 \text {, } \\
p<0.001) \\
\text { - AUC of early FO for predicting mortality was } 0.78 \\
(p<0.001)\end{array}$ \\
\hline Maitland et al. (79) & $\begin{array}{l}\text { Open randomized } \\
\text { controlled trial } \\
\text { Multicenter } \\
\text { 2009-2011 }\end{array}$ & $\begin{array}{l}3,170 \text { children } \\
60 \text { d-12 y } \\
\text { Severe febrile illness with } \\
\text { impaired perfusion } \\
\text { Stratum A (3141)- saline/ } \\
\text { albumin/no bolus } \\
\text { Stratum B (29)- } \\
\text { saline/albumin bolus in } \\
\text { cases with severe } \\
\text { hypotension }\end{array}$ & $\begin{array}{l}\text { Fluid boluses with increased } \\
48 \mathrm{~h} \text { mortality in critically ill } \\
\text { children with impaired } \\
\text { perfusion }\end{array}$ & $\begin{array}{l}\text { - In stratum A, the } 48 \mathrm{~h} \text { mortality was } \\
10.6,10.5,7.3 \% \text { in the albumin-bolus, saline-bolus, } \\
\text { and control group respectively } \\
\text { - } 28 \mathrm{~d} \text { mortality was } 12.2,12 \text {, and } 8.7 \% \text { in the three } \\
\text { groups respectively }(p=0.004 \text { for bolus vs. control) } \\
\text { - In stratum B, mortality was } 69 \% \text { vs. } 56 \% \text { in the } \\
\text { albumin vs. saline group respectively }(p=0.45)\end{array}$ \\
\hline
\end{tabular}


could have masked a true benefit of LR. Further studies and welldesigned RCTs are needed to clarify the optimal type and dose of resuscitation fluid.

\section{MANAGEMENT OF FLUID OVERLOAD}

Early FO has garnered much attention as it seems to be a more decisive factor than late FO in predicting survival because the peak of illness is typically in first few days post-admission and the CFB curve generally flattens out after this period (58, $59,71,75,76)$. Hence early fluid resuscitation is most likely beneficial, whereas early FO is not. Many studies advocate use of standard concentration drug infusion to prevent iatrogenic FO because many drugs are delivered as dilute solutions which significantly add to the daily fluid intake. This effect can be drastic in infants who are unnecessarily exposed to excess fluid through weight-based infusions (102). The concerns about perioperative hyponatremia in children with use of hypotonic maintenance fluids have been addressed lately via a switch to isotonic fluids $(96,103,104)$.

The lack of a specific recommendation on optimal timing of RRT institution still plagues clinicians. CRRT remains the modality of choice in pediatric critical care. The American College of Critical Care Medicine recommends that a threshold of $10 \%$ should be construed as the time for intervention (14). An expert discussion of the pharmacologic management of FO in critically ill patients was recently published (105). Furosemide effectively achieves diuresis in critically ill children, but RCTs have failed to demonstrate any benefit of diuretics in preventing or treating AKI $(106,107)$. The furosemide stress test can be employed to assess the response to diuretics as resistance only delays RRT initiation (108). Aminophylline and fenoldopam have received medical attention owing to their potential in ameliorating AKI. The KDIGO guidelines recommend the use of a single dose of prophylactic theophylline in infants with severe perinatal asphyxia who are vulnerable to develop AKI (109). Use of these agents in post-cardiac surgery infants has also resulted in an improved excretory function and a reduction in urinary AKI biomarkers $(110,111)$.

\section{ONE SIZE DOES NOT FIT ALL - IS IT WORTHWHILE TO PREDICT FLUID RESPONSIVENESS?}

The prediction of FR (fluid responsiveness) in critically ill children remains largely unembraced to date despite its potential role in obviating FO as only $40-60 \%$ of patients typically respond to fluids by increasing the cardiac output by more than 10$15 \%$ (112). The hemodynamic predictor variables have been classified as static and dynamic. Static variables are volumetric and include preload measures based on a single observation in time, namely maximal end diastolic volume, CVP or pulmonary artery occlusion pressure. Dynamic variables consider the cyclical changes in preload occurring during ventilation which are apparent as changes in stroke volume via the Frank-Starling law. These include systolic pressure variation (SPV), pulse pressure variation (PPV), and stroke volume variation (SVV).
Respiratory variation in aortic blood flow peak velocity has been shown to be the only variable predictive of FR in children $(112,113)$. A recent systematic review demonstrated the limited predictive ability of static and dynamic variables in pediatric patients (112). Static variables did not predict FR in children, similar to the evidence in adults. However, dynamic variables based on arterial blood pressure also did not predict FR unlike adults. This probably could be due to age-related differences in vascular mechanical properties which affect the arterial waveform behavior. Evidence for dynamic variables based on plethysmography was deemed inconclusive. The insensitivity of these variables can be ascribed to numerous reasons, namely low tidal volume ventilation, spontaneous respirations, arrhythmias and valvular regurgitation. Inclusion of baseline contractility may improve the predictive potential of these variables. Standardized volume loading (e.g., $10 \mathrm{ml} / \mathrm{kg}$ ) may not lead to consistent changes in ventricular EDV due to inter-individual variance (114). There is a need to clarify how differences in lung, vascular, and cardiac compliances affect predictive potential of dynamic variables in children as volume loading should be tailored for only those patients who are likely to increase stroke volume.

\section{LIMITATIONS}

Literature on fluid resuscitation in pediatric patients is vast but there is no general consensus on the type and dose of resuscitation fluid. Though there is an association between fluid overload and the risk of BPD in a neonate, there is no consensus or guideline on whether fluid restriction or the management of FO will reduce BPD incidence. This is just one example showing the current lack of knowledge on fluid management in children. Further studies and well-designed RCTs are necessary to provide physicians with optimal guidelines. The limited predictability of fluid responsiveness in children along with limited knowledge on the utility of early goal directed therapy further complicates the management of FO. There is a need for more studies to better clarify the effects of FO and create a standardized set of guidelines to assist physicians with management and decrease adverse outcomes.

\section{CONCLUSIONS}

Managing fluid overload in a critically ill pediatric patient is no simple task and poses a multitude of complications. To begin with, the lack of a proper consensus on a method for calculating FO due to the significant number of uncertainties in estimating intake and output makes management a challenge. While FO itself is not a direct marker of mortality, the adverse effects of FO lead to patients being vulnerable to an increased risk of morbidity and mortality. FO puts patients at a risk of being underdiagnosed with AKI and delays treatment, raises odds for mortality associated with CCRT complications, can lead to increased hospital and ICU stay, and prolonged ventilator support in the critically ill population. Given the current lack of knowledge on fluid management in children, further studies and RCTs are necessary to provide guidelines to physicians. 


\section{AUTHOR CONTRIBUTIONS}

All authors listed have made a substantial, direct and intellectual contribution to the work, and approved it for publication.

\section{REFERENCES}

1. Woodcock TE, Woodcock TM. Revised starling equation and the glycocalyx model of transvascular fluid exchange: an improved paradigm for prescribing intravenous fluid therapy. Br J Anaes. (2012) 108:384-94. doi: 10.1093/bja/aer515

2. O'Connor ME, Prowle JR. Fluid overload. Crit Care Clin. (2015) 31:803-21. doi: 10.1016/j.ccc.2015.06.013

3. Chelazzi C, Villa G, Mancinelli P, De Gaudio A, Adembri C. Glycocalyx and sepsis-induced alterations in vascular permeability. Crit Care (2015) 19:26. doi: 10.1186/s13054-015-0741-Z

4. Schmidt EP, Yang Y, Janssen WJ, Gandjeva A, Perez MJ, Barthel L, et al. The pulmonary endothelial glycocalyx regulates neutrophil adhesion and lung injury during experimental sepsis. Nat Med. (2012) 18:1217-23. doi: $10.1038 / \mathrm{nm} .2843$

5. Steppan J, Hofer S, Funke B, Brenner T, Henrich M, Martin E, et al. Sepsis and major abdominal surgery lead to flaking of the endothelial glycocalix. $J$ Surg Res. (2011) 165:136-41. doi: 10.1016/j.jss.2009.04.034

6. Nieuwdorp $M$, van Haeften TW, Gouverneur LG, Mooij HL, van Lieshout HP, Levi M, et al. Loss of endothelial glycocalyx during acute hyperglycemia coincides with endothelial dysfunction and coagulation activation in vivo. Diabetes (2006) 55:480-6. doi: 10.2337/diabetes.55.02.06. db05-1103

7. Rehm M, Bruegger D, Christ F, Conzen P, Thiel M, Jacob M, et al. Shedding of the endothelial glycocalyx in patients undergoing major vascular surgery with global and regional ischemia. Circulation (2007) 116:1896-906. doi: 10.1161/CIRCULATIONAHA.106.684852

8. Bruegger D, Jacob M, Rehm M, Loetsch M, Welsch U, Conzen P, et al. Atrial natriuretic peptide induces shedding of endothelial glycocalyx in coronary vascular bed of guinea pig hearts. Am J Physiol Heart Circul Physiol. (2005) 289:H1993-9. doi: 10.1152/ajpheart.00218.2005

9. Chappell D, Bruegger D, Potzel J, Jacob M, Brettner F, Vogeser $\mathrm{M}$, et al. Hypervolemia increases release of atrial natriuretic peptide and shedding of the endothelial glycocalyx. Crit Care (2014) 18:538. doi: 10.1186/s13054-014-0538-5

10. Bruegger D, Schwartz L, Chappell D, Jacob M, Rehm M, Vogeser M, et al. Release of atrial natriuretic peptide precedes shedding of the endothelial glycocalyx equally in patients undergoing on- and off-pump coronary artery bypass surgery. Basic Res Cardiol. (2011) 106:1111-21. doi: 10.1007/s00395-011-0203-y

11. Lombel RM, Kommareddi M, Mottes T, Selewski DT, Han YY, Gipson DS, et al. Implications of different fluid overload definitions in pediatric stem cell transplant patients requiring continuous renal replacement therapy. Intens Care Med. (2012) 38:663-69. doi: 10.1007/s00134-012-2503-6

12. Goldstein SL, Currier H, Graf JM, Cosio CC, Brewer ED, Sachdeva R. Outcome in children receiving continuous venovenous hemofiltration. Pediatrics (2001) 107:1309-12. doi: 10.1542/peds.107. 6.1309

13. van Asperen Y, Brand LP, Bekhof J. Reliability of the fluid balance in neonates. Acta Paediatr. (2012) 101:479-83. doi: 10.1111/j.1651-2227.2012.02591.x

14. Davis AL, Carcillo JA, Aneja RK, Deymann AJ, Lin JC, Nguyen TC, et al. American College of critical care medicine clinical practice parameters for hemodynamic support of pediatric and neonatal septic shock. Crit Care Med. (2017) 45:1061-93. doi: 10.1097/CCM.0000000000002425

15. Selewski DT, Cornell TT, Lombel RM, Blatt NB, Han YY, Mottes $\mathrm{T}$, et al. Weight-based determination of fluid overload status and mortality in pediatric intensive care unit patients requiring continuous renal replacement therapy. Intens Care Med. (2011) 37:1166-73. doi: $10.1007 / \mathrm{s} 00134-011-2231-3$
RR, SKS, NW and SBB conceptualized the study. RR, SKS, NW and SBB wrote the review. MV and VK made significant contributions in writing, editing and revising the study.

16. Hazle MA, Gajarski RJ, Yu S, Donohue J, Blatt NB. Fluid overload in infants following congenital heart surgery. Pediatr Crit Care Med. (2013) 14:44-9. doi: 10.1097/PCC.0b013e3182712799

17. Benoit G, Phan V, Duval M, Champagne M, Litalien C, Merouani A. Fluid balance of pediatric hematopoietic stem cell transplant recipients and intensive care unit admission. Pediatr Nephrol. (2006) 22:441-7. doi: 10.1007/s00467-006-0331-z

18. Bontant T, Matrot B, Abdoul H, Aizenfisz S, Naudin J, Jones P, et al. Assessing fluid balance in critically ill pediatric patients. Eur J Pediatr. (2014) 174:133-7. doi: 10.1007/s00431-014-2372-9

19. Perren A, Markmann M, Merlani G, Marone C, Merlani P. Fluid balance in critically ill patients. Should we really rely on it? Minerva Anestesiol. (2011) 77:802-11.

20. Mank A, Semin-Goossens A, Lelie JV, Bakker P, Vos R. Monitoring hyperhydration during high-dose chemotherapy: body weight or fluid balance? Acta Haematol. (2003) 109:163-8. doi: 10.1159/000070964

21. Eastwood GM. Evaluating the reliability of recorded fluid balance to approximate body weight change in patients undergoing cardiac surgery. Heart Lung J Acute Crit Care (2006) 35:27-33. doi: 10.1016/j.hrtlng.2005.06.001

22. Kelm DJ, Perrin JT, Cartin-Ceba R, Gajic O, Schenck L, Kennedy CC. Fluid overload in patients with severe sepsis and septic shock treated with early goal-directed therapy is associated with increased acute need for fluidrelated medical interventions and hospital death. Shock (2015) 43:68-73. doi: 10.1097/SHK.0000000000000268

23. Prowle JR, Echeverri JE, Ligabo EV, Ronco C, Bellomo R. Fluid balance and acute kidney injury. Nat Rev Nephrol. (2009) 6:107-15. doi: 10.1038/nrneph.2009.213

24. Rajendram R, Prowle JR. Venous congestion: are we adding insult to kidney injury in sepsis? Crit Care (2014) 18:104. doi: 10.1186/cc13709

25. Carlotti APCP, Carvalho WB. Abdominal compartment syndrome: a review. Pediatr Crit Care Med. (2009) 10:115-20. doi: 10.1097/PCC.0b013e31819371b2

26. Basu RK, Chawla LS, Wheeler DS, Goldstein SL. Renal angina: an emerging paradigm to identify children at risk for acute kidney injury. Pediatr Nephrol. (2011) 27:1067-78. doi: 10.1007/s00467-011-2024-5

27. Macedo E, Bouchard J, Soroko SH, Chertow GM, Himmelfarb J, Ikizker TA, et al. Fluid accumulation, recognition and staging of acute kidney injury in critically-ill patients. Crit Care (2010) 14:R82. doi: 10.1186/ cc9004

28. Cerda J, Cerda M, Kilcullen P, Prendergast J. In severe acute kidney injury, a higher serum creatinine is paradoxically associated with better patient survival. Nephrol Dialys Transplant. (2007) 22:2781-4. doi: 10.1093/ndt/gfm395

29. Basu RK, Andrews A, Krawczeski C, Manning P, Wheeler DS, Goldstein SL. Acute kidney injury based on corrected serum creatinine is associated with increased morbidity in children following the arterial switch operation. Pediatr Crit Care Med. (2013) 14:e218-24. doi: 10.1097/PCC.0b013e3182772f61

30. Liu KD, Thompson BT, Ancukiewicz M, Steingrub JS, Douglas IS, Matthay MA, et al. Acute kidney injury in patients with acute lung injury: Impact of fluid accumulation on classification of acute kidney injury and associated outcomes*. Crit Care Med. (2011) 39:2665-71. doi: 10.1097/CCM.0b013e318228234b

31. Wiedemann HP, Wheeler AP, Bernard GR. Comparison of two fluidmanagement strategies in acute lung injury. J Vasc Surg. (2006) 44:909. doi: 10.1016/j.jvs.2006.08.053

32. Willson DF, Thomas NJ, Tamburro R, Truemper E, Truwit J, Conaway M, et al. The relationship of fluid administration to outcome in the pediatric 
calfactant in acute respiratory distress syndrome trial*. Pediatr Crit Care Med. (2013) 14:666-72. doi: 10.1097/PCC.0b013e3182917cb5

33. Arikan AA, Zappitelli M, Goldstein SL, Naipaul A, Jefferson LS, Loftis LL. Fluid overload is associated with impaired oxygenation and morbidity in critically ill children*. Pediatr Crit Care Med. (2012) 13:253-8. doi: 10.1097/PCC.0b013e31822882a3

34. Li Y, Wang J, Bai Z, Chen J, Wang X, Pan J, et al. Early fluid overload is associated with acute kidney injury and PICU mortality in critically ill children. Eur J Pediatr. (2015) 175:39-48. doi: 10.1007/s00431-015-2592-7

35. Brandstrup B, Tønnesen H, Beier-Holgersen R, Hjortsø E, Ørding $\mathrm{H}$, Lindorff-Larsen $\mathrm{K}$, et al. Effects of intravenous fluid restriction on postoperative complications: comparison of two perioperative fluid regimens. Ann Surg. (2003) 238:641-8. doi: $10.1097 / 01$. sla.0000094387.50865.23

36. Grams ME, Estrella MM, Coresh J, Brower RG, Liu KD. Fluid balance, diuretic use, and mortality in acute kidney injury. Clin J Am Soc Nephrol. (2011) 6:966-73. doi: 10.2215/CJN.08781010

37. Abulebda K, Cvijanovich NZ, Thomas NJ, Allen GL, Anas N, Bigham MT, et al. Post-ICU admission fluid balance and pediatric septic shock outcomes. Crit Care Med. (2014) 42:397-403. doi: 10.1097/CCM.0b013e3182a64607

38. de Galasso L, Emma F, Picca S, Di Nardo M, Rossetti E, Guzzo I. Continuous renal replacement therapy in children: fluid overload does not always predict mortality. Pediatr Nephrol. (2016) 31:651-9. doi: 10.1007/s00467-015-3248-6

39. Flores FX, Brophy D, Symons JM, Fortenberry JD, Chua AN, Alexander SR, et al. Continuous renal replacement therapy (CRRT) after stem cell transplantation. A report from the prospective pediatric CRRT Registry Pediatric Nephrol. (2008) 23:625-30. doi: 10.1007/s00467-007-0672-2

40. Selewski DT, Askenazi DJ, Bridges BC, Cooper DS, Fleming GM, Paden ML, et al. The impact of fluid overload on outcomes in children treated with extracorporeal membrane oxygenation: a multicenter retrospective cohort study. Pediatr Crit Care Med. (2017) 18:1126-35. doi: 10.1097/PCC.0000000000001349

41. Sutherland SM, Zappitelli M, Alexander SR, Chua AN, Brophy D, Bunchman TE, et al. Fluid overload and mortality in children receiving continuous renal replacement therapy: the prospective pediatric continuous renal replacement therapy registry. Am J Kidney Dis. (2010) 55:316-25. doi: 10.1053/j.ajkd.2009.10.048

42. Hayes LW, Oster RA, Tofil NM, Tolwani AJ. Outcomes of critically ill children requiring continuous renal replacement therapy. J Crit Care (2009) 24:394-400. doi: 10.1016/j.jcrc.2008.12.017

43. Goldstein SL, Somers JG, Baum MA, Symons JM, Brophy D, Blowey D, et al. Pediatric patients with multi-organ dysfunction syndrome receiving continuous renal replacement therapy. Kidney Int. (2005) 67:653-8. doi: 10.1111/j.1523-1755.2005.67121.x

44. Gillespie RS, Seidel K, Symons JM. Effect of fluid overload and dose of replacement fluid on survival in hemofiltration. Pediatr Nephrol. (2004) 19:1394-9. doi: 10.1007/s00467-004-1655-1

45. Foland JA, Fortenberry JD, Warshaw BL, Pettignano R, Merritt RK, Heard $\mathrm{ML}$, et al. Fluid overload before continuous hemofiltration and survival in critically ill children: A retrospective analysis*. Crit Care Med. (2004) 32:1771-76. doi: 10.1097/01.CCM.0000132897.52737.49

46. Bellomo R, Cass A, Cole L, Finfer S, Gallagher M, Lee J, et al. An observational study fluid balance and patient outcomes in the randomized evaluation of normal vs. augmented level of replacement therapy trial. Crit Care Med. (2012) 40:1753-60. doi: 10.1097/CCM.0b013e318246b9c6

47. Bouchard J, Soroko SB, Chertow GM, Himmelfarb J, Ikizler TA, Paganini EP, et al. Fluid accumulation, survival and recovery of kidney function in critically ill patients with acute kidney injury. Kidney Int. (2009) 76:422-7. doi: $10.1038 / \mathrm{ki} .2009 .159$

48. Mehta RL, Bouchard J, Soroko SB, Ikizler TA, Paganini EP, Chertow GM, et al. Sepsis as a cause and consequence of acute kidney injury: Program to improve care in acute renal disease. Intens Care Med. (2010) 37:241-8. doi: 10.1007/s00134-010-2089-9

49. Selewski DT, Cornell TT, Blatt NB, Han YY, Mottes T, Kommareddi M, et al. Fluid overload and fluid removal in pediatric patients on extracorporeal membrane oxygenation requiring continuous renal replacement therapy*. Crit Care Med. (2012) 40:2694-9. doi: 10.1097/CCM.0b013e318258ff01
50. Zangrillo A, Landoni G, Biondi-Zoccai G, Greco M, Greco T, Frati G, et al. A meta-analysis of complications and mortality of extracorporeal membrane oxygenation. Crit Care Resusc. (2013) 15:172-8.

51. Wolf MJ, Chanani NK, Heard ML, Kanter KR, Mahle WT. Early renal replacement therapy during pediatric cardiac extracorporeal support increases mortality. Ann Thorac Surg. (2013) 96:917-22. doi: 10.1016/j.athoracsur.2013.05.056

52. Paden ML, Warshaw BL, Heard ML, Fortenberry JD. Recovery of renal function and survival after continuous renal replacement therapy during extracorporeal membrane oxygenation*. Pediatr Crit Care Med. (2011) 12:153-8. doi: 10.1097/PCC.0b013e3181e2a596

53. Blinder JJ, Goldstein SL, Lee V, Baycroft A, Fraser CD, Nelson D, et al. Congenital heart surgery in infants: effects of acute kidney injury on outcomes. J Thorac Cardiovasc Surg. (2012) 143:368-74. doi: 10.1016/j.jtcvs.2011.06.021

54. Lex DJ, Tóth R, Czobor NR, Alexander SI, Breuer T, Sápi E, et al. Fluid overload is associated with higher mortality and morbidity in pediatric patients undergoing cardiac surgery*. Pediatr Crit Care Med. (2016) 17:30714. doi: 10.1097/PCC.0000000000000659

55. Grist G, Whittaker C, Merrigan K, Fenton J, Worrall E, O'Brien J, et al. The correlation of fluid balance changes during cardiopulmonary bypass to mortality in pediatric and congenital heart surgery patients. J Extra Corpor Technol. (2011) 43:215-26.

56. Sampaio TZAL, O'Hearn K, Reddy D, Menon K. The influence of fluid overload on the length of mechanical ventilation in pediatric congenital heart surgery. Pediatr Cardiol. (2015) 36:1692-9. doi: 10.1007/s00246-015-1219-0

57. Piggott KD, Soni M, Decampli WM, Ramirez JA, Holbein D, Fakioglu H, et al. Acute kidney injury and fluid overload in neonates following surgery for congenital heart disease. World J Pediatr Cong Heart Surg. (2015) 6:401-6. doi: $10.1177 / 2150135115586814$

58. Seguin J, Albright B, Vertullo L, Lai P, Dancea A, Bernier L, et al. Extent, risk factors, and outcome of fluid overload after pediatric heart surgery*. Crit Care Med. (2014) 42:2591-9. doi: 10.1097/CCM.0000000000000517

59. Hassinger AB, Wald EL, Goodman DM. Early postoperative fluid overload precedes acute kidney injury and is associated with higher morbidity in pediatric cardiac surgery patients. Pediatr Crit Care Med. (2014) 15:131-8. doi: 10.1097/PCC.0000000000000043

60. Saini A, Delius RE, Seshadri S, Walters H, Mastropietro CW. Passive peritoneal drainage improves fluid balance after surgery for congenital heart disease. Eur J Cardio Thorac Surg. (2011) 41:256-60. doi: 10.1016/j.ejcts.2011.05.037

61. Sasser WC, Dabal RJ, Askenazi DJ, Borasino S, Moellinger AB, Kirklin JK, et al. Prophylactic peritoneal dialysis following cardiopulmonary bypass in children is associated with decreased inflammation and improved clinical outcomes. Cong Heart Dis. (2013) 9:106-15. doi: 10.1111/chd.12072

62. Kwiatkowski DM, Menon S, Krawczeski CD, Goldstein SL, D.Morales LS, Phillips A, et al. Improved outcomes with peritoneal dialysis catheter placement after cardiopulmonary bypass in infants. J Thorac Cardiovasc Surg. (2015) 149:230-6. doi: 10.1016/j.jtcvs.2013.11.040

63. Ryerson LM, Mackie AS, Atallah J, Joffe AR, Rebeyka IM, Ross DB, et al. Prophylactic peritoneal dialysis catheter does not decrease time to achieve a negative fluid balance after the Norwood procedure: a randomized controlled trial. J Thorac Cardiovasc Surg. (2015) 149:222-8. doi: $10.1016 /$ j.jtcvs.2014.08.011

64. Oh W, Poindexter BB, Perritt R, Lemons JA, Bauer CR, Ehrenkranz RA, et al. Association between fluid intake and weight loss during the first ten days of life and risk of bronchopulmonary dysplasia in extremely low birth weight infants. J Pediatr. (2005) 147:786-90. doi: 10.1016/j.jpeds.2005.06.039

65. Schmidt B, Roberts RS, Fanaroff A, Davis P, Kirpalani HM, Nwaesei $\mathrm{C}$, et al. Indomethacin prophylaxis, patent ductus arteriosus, and the risk of bronchopulmonary dysplasia: further analyses from the Trial of Indomethacin Prophylaxis in Preterms (TIPP). J Pediatr. (2006) 148:7304.e1. doi: 10.1016/j.jpeds.2006.01.047

66. Marshall DD, Kotelchuck M, Young TE, Bose CL, Kruyer L, O’Shea TM. Risk factors for chronic lung disease in the surfactant era: a North Carolina population-based study of very low birth weight infants. Pediatrics (1999) 104:1345-50. doi: 10.1542/peds.104.6.1345 
67. Askenazi D, Patil NR, Ambalavanan N, Balena-Borneman J, Lozano DJ, Ramani M, et al. Acute kidney injury is associated with bronchopulmonary dysplasia/mortality in premature infants. Pediatr Nephrol. (2015) 30:1511-8. doi: 10.1007/s00467-015-3087-5

68. Swaniker F, Kolla S, Moler F, Custer J, Grams R, Bartlett R, et al. Extracorporeal life support outcome for 128 pediatric patients with respiratory failure. J Pediatric Surg. (2000) 35:197-202. doi: 10.1016/S0022-3468(00)90009-5

69. Lee ST, Cho H. Fluid overload and outcomes in neonates receiving continuous renal replacement therapy. Pediatric Nephrol. (2016) 31:2145-52. doi: 10.1007/s00467-016-3363-z

70. Askenazi DJ, Koralkar R, Hundley HE, Montesanti A, Patil N, Ambalavanan N. Fluid overload and mortality are associated with acute kidney injury in sick near-term/term neonate. Pediatr Nephrol. (2012) 28:661-6. doi: 10.1007/s00467-012-2369-4

71. Ingelse SA, Wiegers MG, Calis JC, van Woensel JB, Bem RA. Early fluid overload prolongs mechanical ventilation in children with virallower respiratory tract disease*. Pediatr Crit Care Med. (2017) 18:e106-11. doi: 10.1097/PCC.0000000000001060

72. Sinitsky L, Walls D, Nadel S, Inwald DP. Fluid overload at 48 hours is associated with respiratory morbidity but not mortality in a general PICU. Pediatr Crit Care Med. (2015) 16:205-9. doi: 10.1097/PCC.0000000000000318

73. Valentine SL, Sapru A, Higgerson RA, Spinella C, Flori HR, Graham DA, et al. Fluid balance in critically ill children with acute lung injury* . Crit Care Med. (2012) 40:2883-9. doi: 10.1097/CCM.0b013e31825bc54d

74. Flori HR, Church G, Liu KD, Gildengorin G, Matthay MA. Positive fluid balance is associated with higher mortality and prolonged mechanical ventilation in pediatric patients with acute lung injury. Crit Care Res Pract. (2011) 2011:1-5. doi: 10.1155/2011/854142

75. Chen J, Li X, Bai Z, Fang F, Hua J, Li Y, et al. Association of fluid accumulation with clinical outcomes in critically ill children with severe sepsis. PLOS ONE (2016) 11:e0160093. doi: 10.1371/journal.pone.0160093

76. Bhaskar P, Dhar AV, Thompson M, Quigley R, Modem V. Early fluid accumulation in children with shock and ICU mortality: a matched case-control study. Intens Care Med. (2015) 41:1445-53. doi: 10.1007/s00134-015-3851-9

77. Hoover NG, Heard M, Reid C, Wagoner S, Rogers K, Foland J, et al. Enhanced fluid management with continuous venovenous hemofiltration in pediatric respiratory failure patients receiving extracorporeal membrane oxygenation support. Intens Care Med. (2008) 34:2241-7. doi: $10.1007 /$ s00134-008-1200-y

78. Blijdorp K, Cransberg K, Wildschut ED, Gischler SJ, Jan Houmes R, Wolff ED, et al. Haemofiltration in newborns treated with extracorporeal membrane oxygenation: a case-comparison study. Crit Care (2009) 13:R48. doi: $10.1186 /$ cc7771

79. Maitland K, Kiguli S, Opoka RO, Engoru C, Olupot-Olupot P, Akech SO, et al. Mortality after Fluid Bolus in African Children with Severe Infection. N Engl J Med. (2011) 364:2483-95. doi: 10.1056/NEJMoa1101549

80. McCann EM, Lewis K, Deming DD, Donovan MJ, Brady JP. Controlled trial of furosemide therapy in infants with chronic lung disease. J Pediatr. (1985) 106:957-62. doi: 10.1016/S0022-3476(85)80252-3

81. Barrington KJ, Fortin-Pellerin E, Pennaforte T. Fluid restriction for treatment of preterm infants with chronic lung disease. Cochr Database Syst Rev. (2017) 2:Cd005389. doi: 10.1002/14651858.CD005389.pub2

82. Grissom CK, Hirshberg EL, Dickerson JB, Brown SM, Lanspa MJ, Liu KD, et al. Fluid management with a simplified conservative protocol for the acute respiratory distress syndrome*. Crit Care Med. (2015) 43:288-95. doi: 10.1097/CCM.0000000000000715

83. Rivers E, Nguyen B, Havstad S, Ressler J, Muzzin A, Knoblich B, et al. Early goal-directed therapy in the treatment of severe sepsis and septic shock. $N$ Engl J Med. (2001) 345:1368-77. doi: 10.1056/NEJMoa010307

84. Akcan Arikan A, Williams EA, Graf JM, Kennedy CE, Patel B, Cruz AT. Resuscitation bundle in pediatric shock decreases acute kidney injury and improves outcomes. J Pediatr. (2015) 167:1301-5 e1. doi: 10.1016/j.jpeds.2015.08.044

85. Han YY, Carcillo JA, Dragotta MA, Bills DM, Watson RS, Westerman $\mathrm{ME}$, et al. Early reversal of pediatric-neonatal septic shock by community physicians is associated with improved outcome. Pediatrics (2003) 112:7939. doi: 10.1542/peds.112.4.793

86. Kissoon N, Orr RA, Carcillo JA. Updated American College of Critical Care Medicine-pediatric advanced life support guidelines for management of pediatric and neonatal septic shock. Pediatr Emerg Care (2010) 26:867-9. doi: 10.1097/PEC.0b013e3181fb0dc0

87. Oliveira CF, Nogueira de Sá FR, Oliveira SF, Gottschald FC, Moura DG, Shibata RO, et al. Time- and fluid-sensitive resuscitation for hemodynamic support of children in septic shock. Pediatr Emerg Care (2008) 24:810-5. doi: 10.1097/PEC.0b013e31818e9f3a

88. de Oliveira CF, D.de Oliveira SF, Gottschald FC, Moura DG, Costa GA, Ventura AC, et al. ACCM/PALS haemodynamic support guidelines for paediatric septic shock: an outcomes comparison with and without monitoring central venous oxygen saturation. Intens Care Med. (2008) 34:1065-75. doi: 10.1007/s00134-008-1085-9

89. Peake SL, Delaney A, Bailey M, Bellomo R, ARISE Investigators. Goaldirected resuscitation for patients with early septic shock. $N$ Engl J Med. (2014) 371:1496-506. doi: 10.1056/NEJMoa1404380

90. Mouncey PR, Osborn TM, Power GS, Harrison DA, Sadique MZ, Grieve RD, et al. Trial of early, goal-directed resuscitation for septic shock. N Engl J Med. (2015) 372:1301-11. doi: 10.1056/NEJMoa1500896

91. Yealy DM, Kellum JA, Huang DT, Barnato AE, Weissfeld LA, Pike F, et al. A randomized trial of protocol-based care for early septic shock. $N$ Engl J Med. (2014) 370:1683-93. doi: 10.1056/NEJMoa1401602

92. Dellinger RP, Levy MM, Rhodes A, Annane D, Gerlach H, Opal SM, et al. Surviving sepsis campaign: international guidelines for management of severe sepsis and septic shock 2012. Intens Care Med. (2013) 39:165-228. doi: 10.1007/s00134-012-2769-8

93. Yu H, Chi D, Wang S, Liu B. Effect of early goal-directed therapy on mortality in patients with severe sepsis or septic shock: a metaanalysis of randomised controlled trials. BMJ Open (2016) 6:e008330. doi: 10.1136/bmjopen-2015-008330

94. Zhang L, Zhu G, Han L, Fu P. Early goal-directed therapy in the management of severe sepsis or septic shock in adults: a meta-analysis of randomized controlled trials. BMC Med. (2015) 13:71. doi: 10.1186/s12916-0150312-9

95. Workman JK, Ames SG, Reeder RW, Korgenski EK, Masotti SM, Bratton SL, et al. Treatment of pediatric septic shock with the surviving sepsis campaign guidelines and PICU patient outcomes*. Pediatr Crit Care Med. (2016) 17:e451-8. doi: 10.1097/PCC.0000000000000906

96. Carcillo JA. Intravenous fluid choices in critically ill children. Curr Opin Crit Care (2014) 20:396-401. doi: 10.1097/MCC.00000000000 00119

97. Pediatric Acute Respiratory Distress Syndrome: Consensus Recommendations From the Pediatric Acute Lung Injury Consensus Conference. Pediatr Crit Care Med. (2015) 16: 428-39. doi: 10.1097/PCC.0000000000000350

98. Rhodes A, Evans LE, Alhazzani W, Levy MM, Antonelli M, Ferrer R, et al. Surviving sepsis campaign: international guidelines for management of sepsis and septic shock: 2016. Intens Care Med. (2017) 43:304-77. doi: 10.1007/s00134-017-4683-6

99. Booy R. Reduction in case fatality rate from meningococcal disease associated with improved healthcare delivery. Arch Dis Child. (2001) 85:38690. doi: 10.1136/adc.85.5.386

100. Maitland K, Pamba A, English M, Peshu N, Marsh K, Newton C, et al. Randomized Trial of volume expansion with albumin or saline in children with severe malaria: preliminary evidence of albumin benefit. Clin Infect Dis. (2005) 40:538-45. doi: 10.1086/427505

101. Weiss SL, Keele L, Balamuth F, Vendetti N, Ross R, Fitzgerald JC, et al. Crystalloid fluid choice and clinical outcomes in pediatric sepsis: a matched retrospective cohort study. J Pediatr. (2017) 182:304-10.e10. doi: 10.1016/j.jpeds.2016.11.075

102. Sutherland A, Jemmett E, Playfor S. The impact of fixed concentrations sedation infusions on fluid overload in critically ill children. Arch Dis Child. (2016) 101:e2.43-e2. doi: 10.1136/archdischild-2016-311535.48

103. Oh GJ, Sutherland SM. Perioperative fluid management and postoperative hyponatremia in children. Pediatr Nephrol. (2015) 31:53-60. doi: 10.1007/s00467-015-3081-y 
104. Wang J, Xu E, Xiao Y. Isotonic versus hypotonic maintenance IV fluids in hospitalized children: a meta-analysis. Pediatrics (2013) 133:105-13. doi: 10.1542/peds.2013-2041

105. Goldstein S, Bagshaw S, Cecconi M, Okusa M, Wang H, Kellum J, et al. Pharmacological management of fluid overload. Br J Anaesthes. (2014) 113:756-63. doi: 10.1093/bja/aeu299

106. Wald EL, Finer G, McBride ME, Nguyen N, Costello JM, Epting CL. Fluid management. Pediatr Crit Care Med. (2016) 17:S257-65. doi: 10.1097/PCC.0000000000000781

107. van der Voort PHJ, Boerma EC, Koopmans M, Zandberg M, de Ruiter J, Gerritsen RT, et al. Furosemide does not improve renal recovery after hemofiltration for acute renal failure in critically ill patients: a double blind randomized controlled trial*. Crit Care Med. (2009) 37:533-8. doi: 10.1097/CCM.0b013e318 $195424 \mathrm{~d}$

108. Chawla LS, Davison DL, Brasha-Mitchell E, Koyner JL, Arthur JM, Shaw $\mathrm{AD}$, et al. Development and standardization of a furosemide stress test to predict the severity of acute kidney injury. Crit Care (2013) 17:R207. doi: $10.1186 / \mathrm{cc} 13015$

109. Kidney Disease: Improving Global Outcomes (KDIGO) CKD-MBD Update Work GrouKDIGO 2017 Clinical Practice Guideline Update for the Diagnosis, Evaluation, Prevention, and Treatment of Chronic Kidney Disease-Mineral and Bone Disorder (CKD-MBD). Kidney International Supplements (2017) $7: e 1$.

110. Axelrod DM, Anglemyer AT, Sherman-Levine SF, Zhu A, Grimm C, Roth SJ, et al. Initial Experience using aminophylline to improve renal dysfunction in the pediatric cardiovascular ICU. Pediatr Crit Care Med. (2014) 15:21-7. doi: 10.1097/01.pcc.0000436473.12082.2f

111. Moffett BS, Mott AR, Nelson DP, Goldstein SL, Jefferies JL. Renal effects of fenoldopam in critically ill pediatric patients: a retrospective review. Pediatr Crit Care Med. (2008) 9:403-6. doi: 10.1097/PCC.0b013e3181728c25

112. Gan H, Cannesson M, Chandler JR, Ansermino JM. Predicting fluid responsiveness in children. Anesthes Analges. (2013) 117:1380-92. doi: 10.1213/ANE.0b013e3182a9557e

113. Saxena R, Durward A, Steeley S, Murdoch IA, Tibby SM. Predicting fluid responsiveness in 100 critically ill children: the effect of baseline contractility. Intens Care Med. (2015) 41:2161-9. doi: 10.1007/s00134-015-4075-8

114. Lukito V, Djer MM, Pudjiadi AH, Munasir Z. The role of passive leg raising to predict fluid responsiveness in pediatric intensive care unit patients*. Pediatr Crit Care Med. (2012) 13:e155-60. doi: 10.1097/PCC.0b013e3182388ab3

Conflict of Interest Statement: The authors declare that the research was conducted in the absence of any commercial or financial relationships that could be construed as a potential conflict of interest.

Copyright (C) 2018 Raina, Sethi, Wadhwani, Vemuganti, Krishnappa and Bansal. This is an open-access article distributed under the terms of the Creative Commons Attribution License (CC BY). The use, distribution or reproduction in other forums is permitted, provided the original author(s) and the copyright owner(s) are credited and that the original publication in this journal is cited, in accordance with accepted academic practice. No use, distribution or reproduction is permitted which does not comply with these terms. 